\title{
Sperm wars and the evolution of male fertility
}

\author{
Leigh W Simmons and John L Fitzpatrick \\ Centre for Evolutionary Biology, School of Animal Biology (M092), The University of Western Australia, Crawley, \\ Western Australia 6009, Australia
}

Correspondence should be addressed to LW Simmons; Email: leigh.simmons@uwa.edu.au

\begin{abstract}
Females frequently mate with several males, whose sperm then compete to fertilize available ova. Sperm competition represents a potent selective force that is expected to shape male expenditure on the ejaculate. Here, we review empirical data that illustrate the evolutionary consequences of sperm competition. Sperm competition favors the evolution of increased testes size and sperm production. In some species, males appear capable of adjusting the number of sperm ejaculated, depending on the perceived levels of sperm competition. Selection is also expected to act on sperm form and function, although the evidence for this remains equivocal. Comparative studies suggest that sperm length and swimming speed may increase in response to selection from sperm competition. However, the mechanisms driving this pattern remain unclear. Evidence that sperm length influences sperm swimming speed is mixed and fertilization trials performed across a broad range of species demonstrate inconsistent relationships between sperm form and function. This ambiguity may in part reflect the important role that seminal fluid proteins (sfps) play in affecting sperm function. There is good evidence that sfps are subject to selection from sperm competition, and recent work is pointing to an ability of males to adjust their seminal fluid chemistry in response to sperm competition from rival males. We argue that future research must consider sperm and seminal fluid components of the ejaculate as a functional unity. Research at the genomic level will identify the genes that ultimately control male fertility.

Reproduction (2012) 144 519-534
\end{abstract}

\section{Introduction}

Originally, it was thought that females required very few mating partners in order to realize their maximum reproductive potential (Bateman 1948). However, research over the last few decades has shown us how mating with multiple males (polyandry) is a taxonomically widespread female reproductive strategy (Simmons 2005). Females can increase their reproductive success by accepting copulations from multiple males, via resources provided by males, insurance against male infertility, or via the opportunity that multiple inseminations provide females for choosing the best sires for their offspring (Sheldon 1994, Arnqvist \& Nilsson 2000, Simmons 2005, Slatyer et al. 2012). While females may gain benefits from mating with multiple males, the consequence of polyandry for males is that their sperm may face competition from the sperm of other males to fertilize a limited supply of ova.

Parker (1970) recognized that sperm competition would favor the evolution of male reproductive morphology, physiology, and behavior that promotes competitive fertilization success. In the ensuing 40 years since Parker's pioneering insights, numerous game theoretical models have been developed to predict how sperm competition influences evolutionary responses in male reproductive traits (reviewed by Parker \& Pizzari (2010)). In particular, because it is the ejaculate that is at the frontline of competition, extensive attention has been devoted to modeling how sperm competition influences rates of sperm production, the quality of sperm, and male expenditure on the ejaculate under various competitive scenarios. However, sperm are, but one part of the ejaculate and recent theoretical attention has been devoted to understanding how sperm competition shapes male investment in the non-sperm component of the ejaculate, the seminal fluid (Hodgson \& Hosken 2006, Cameron et al. 2007, Alonzo \& Pizzari 2010, Fromhage 2012). The aim of this review is to provide a broad overview of adaptations in male ejaculate biology that are thought to have arisen as evolutionary consequences of the war between males for gaining fertilizations. We therefore look at sperm competition from the male perspective. We briefly describe the rich theoretical framework aimed at understanding how selection acts on the ejaculate (sperm and seminal fluid) and examine the evidence for sperm competition being a significant factor in the evolution of male fertility. We show how male investment in sperm production is indeed acutely sensitive to female mating behavior, both within and among species, and reveal 
how selection acts not just on sperm production but also on sperm form and function, and the protein-rich seminal fluids within which sperm are transferred to the female.

\section{Sperm: solders in the battle for fertilization Testes size and sperm production}

Game theoretical models have been developed to predict the evolutionary response of males to the probability that females will mate with more than one male (sperm competition risk) and the number of males that a female will typically accept (sperm competition intensity) (Parker \& Pizzari 2010). These models assume that sperm production is costly insofar as resources invested in sperm production are unavailable for future survival and reproduction. Risk models are designed to make predictions for low levels of sperm competition where females have a given probability of mating with just two males. Intensity models are designed for high levels of sperm competition, where typically more than two males compete. Thus, in species where females are monogamous, males are predicted to invest minimally in their ejaculates, ensuring their functional fertility while maximizing their survival for future reproductive opportunities. As the levels of sperm competition increases across species, the males of a species should be selected to increase their expenditure on the ejaculate at the cost to future reproduction, a prediction for which there is much evidence.

Increases in testes size represent one of the most wellcharacterized evolutionary responses to sperm competition (Birkhead \& Møller 1998, Simmons 2001). Typically, males that inseminate greater numbers of sperm achieve greater fertilization success (Martin et al. 1974, Parker 1982). As the size of a males' testes predicts the proportion of the testes made up of sperm producing seminiferous tissue and the rate of sperm production (Willett \& Ohms 1957, Parker 1982, Møller 1989, Marconato \& Shapiro 1996, Scharer et al. 2004, Lüpold et al. 2009c, Ramm \& Stockley 2010, Rowe \& Pruett-Jones 2011), males with larger testes are expected to be competitively advantaged when engaging in sperm competition. Consequently, increases in the level of sperm competition are expected to select for increased investment in testicular tissue (Parker \& Pizzari 2010).

There is now taxonomically widespread evidence that sperm production increases with the level of sperm competition, both across and within species. This empirical evidence falls into four broad categories. First, comparative studies reveal that after controlling for body size, relative testes size increases with the level of sperm competition across species (Table 1). Specifically, those species with multi-male mating systems typically have larger testes than species with monogamous mating systems (Table 1). Secondly, within species comparisons among populations demonstrate that males have relatively larger testes in populations where the level of sperm competition is elevated (Gage 1995, Parker et al. 1997, Firman \& Simmons 2008a, Dziminski et al. 2010a). Thirdly, relative testes size exhibits rapid evolutionary responses to the level of sperm competition in experimental evolution studies. For example, in the yellow dung fly Scathopaga stercoraria (Hosken \& Ward 2001), Drosophila melanogaster (Pitnick et al. 2001), and the dung beetle Onthophagus taurus (Simmons \& García-González 2008), experimental populations where monogamous mating conditions were enforced showed decreases in relative testes size over multiple generations compared with experimental populations that evolved under polyandrous mating conditions (but see Wigby \& Chapman (2004), Crudgington et al. (2009) and Firman \& Simmons (2010b) for experimental evolution studies where changes in relative testes size in response to sperm competition were not observed). Finally, clear within species evidence for the influence of sperm competition on testes size comes from studies in insects (Simmons et al. 2007 b) and fishes (Montgomerie \& Fitzpatrick 2009) with alternative reproductive tactics. In these species, males with different phenotypes use different mating behaviors to secure fertilizations: some males fight for and court females while others engage in sneak copulations. Sneaker males, who always experience sperm competition, typically have relatively, and in some cases absolutely, larger testes than courting males, who often mate in the absence of sperm competition (reviewed by Simmons (2001) and Montgomerie \& Fitzpatrick (2009)).

The accumulating evidence that relative testes size increases with the level of sperm competition has led to the widespread acceptance of the role of sperm competition in shaping testes size. So common is this view that many researchers, including the authors of this review (e.g. Fitzpatrick et al. (2012a, 2012b, 2012c)), commonly use relative testes size as a proxy measure for the strength of sperm competition in a given species, even in the absence of any information on a species mating behavior (Møller 1991, Briskie \& Montgomerie 1992, Dunn et al. 2001, Pitcher et al. 2005, Calhim \& Birkhead 2007). However, a degree of caution should be applied to accepting relative testes size as an absolute proxy for the level of sperm competition because testes can perform functions other than sperm production (Emerson 1997), and increased investment in testes mass could be favored in species where copulation occurs frequently (the male mating rate hypotheses) even in the absence of variation in the level of sperm competition (Crudgington et al. 2009, Vahed \& Parker 2012). To clarify and quantify the role of sperm competition in shaping testes size, we feel that there would be great merit in a quantitative meta-analytical review of the relationship between relative testes size and level of sperm competition. 
Table 1 Review of comparative analyses testing the prediction that increased selection from sperm competition should influence investment in testes size (correcting for body size) and commonly assessed sperm traits including sperm morphology (measured as sperm head length, midpiece length, and flagellum/total length), sperm viability, and sperm velocity. In the studies summarized, sperm competition risk is assessed using a variety of methods including data on mating systems, rates of extra-pair paternity, number of spermatophores recovered from female reproductive tracts (for some insect species), frequency of males adopting alternative reproductive tactics, female remating rates, reproductive behaviors, and sexual size dimorphism.

\begin{tabular}{|c|c|c|c|c|c|c|}
\hline \multirow[b]{2}{*}{ Taxa } & \multirow[b]{2}{*}{$\begin{array}{l}\text { Testes } \\
\text { size }\end{array}$} & \multicolumn{3}{|c|}{ Sperm morphology } & \multirow[b]{2}{*}{$\begin{array}{l}\text { Sperm } \\
\text { viability/ } \\
\text { velocity }\end{array}$} & \multirow[b]{2}{*}{ References } \\
\hline & & $\begin{array}{l}\text { Head } \\
\text { length }\end{array}$ & $\begin{array}{l}\text { Mid- } \\
\text { piece } \\
\text { length }\end{array}$ & $\begin{array}{l}\text { Flagellum/ } \\
\text { total } \\
\text { length }\end{array}$ & & \\
\hline \multicolumn{7}{|l|}{ Mammals } \\
\hline Mammals $^{\mathrm{a}}$ &,+ 0 & + &,+ 0 &,+ 0 & + & $\begin{array}{l}\text { Gage et al. (2002), Gage \& Freckleton (2003), Anderson et al. } \\
\text { (2005), Lemaître et al. (2009), Soulsbury (2010) and Tourmente } \\
\text { et al. (2011a) }\end{array}$ \\
\hline Bats & + & NA & NA & 0 & NA & Hosken $(1997,1998)$ and Lemaitre et al. (2009) \\
\hline Rodents & + & + & 0 &,+ 0 & + & $\begin{array}{l}\text { Gomendio \& Roldan (1991), Hosken (1997), Breed \& Taylor (2000), } \\
\text { Ramm et al. (2005), Bryja et al. (2008), Gomendio et al. (2011) } \\
\text { and Montoto et al. (2011a, 2011b) }\end{array}$ \\
\hline Ungulates & + & NA & NA & 0 & NA & $\begin{array}{l}\text { Ginsberg \& Rubenstein (1990), Lemaître et al. (2009) and } \\
\text { Gomendio et al. (2011) }\end{array}$ \\
\hline Carnivores & 0 & NA & NA & 0 & NA & Lemaître et al. (2009) and Gomendio et al. (2011) \\
\hline $\begin{array}{l}\text { Marsupials and } \\
\text { monotremes }\end{array}$ & + & 0 & 0 & + & NA & Rose et al. (1997) and Tourmente et al. (2011b) \\
\hline Primates & + & NA & NA &,+ 0 & + & $\begin{array}{l}\text { Harcourt et al. (1981, 1995), Møller (1988), Gomendio \& Roldan } \\
\text { (1991), Kappeler (1997), Anderson \& Dixon (2002), Nascimento } \\
\text { et al. (2008), Lemaître et al. (2009) and Gomendio et al. (2011) }\end{array}$ \\
\hline Voles & 0 & NA & NA & NA & NA & Heske \& Ostfeld (1990) \\
\hline Pinnipeds & - & NA & NA & NA & NA & Fitzpatrick et al. (2012b) \\
\hline \multicolumn{7}{|r|}{ rILPdtति el di. (2012D) } \\
\hline Birds $^{a}$ & + & + & 0 &,+ 0 & NA & $\begin{array}{l}\text { Møller (1991), Briskie \& Montgomerie (1992), Møller \& Briskie (1995), } \\
\text { Stutchbury \& Morton (1995), Garamszegi et al. (2005), Pitcher et al. } \\
\text { (2005), Immler \& Birkhead (2007) and Immler et al. (2011) }\end{array}$ \\
\hline Finches & NA & 0 & + & + & NA & Immler \& Birkhead (2007) \\
\hline Warblers & NA & 0 & - & - & NA & Immler \& Birkhead (2007) \\
\hline Blackbirds & NA & 0 & + & + & + & Lüpold et al. (2009a, 2009b) \\
\hline Wrens & + & NA & NA & NA & + & Rowe \& Pruett-Jones (2011) \\
\hline Sandpipers & + & NA & NA & NA & NA & Carter (1985) \\
\hline Waterfowl & + & NA & NA & NA & NA & Coker et al. (2002) \\
\hline Raptors & - & NA & NA & NA & NA & Olsen (1991) \\
\hline Pheasants & NA & 0 & 0 & 0 & NA & Immler et al. (2007b) \\
\hline Shorebirds & NA & 0 & 0 & + & NA & Johnson \& Briskie (1999) \\
\hline \multicolumn{7}{|l|}{ Fishes } \\
\hline Fishes $^{\mathrm{a}}$ & + & NA & NA &,+- & NA & $\begin{array}{l}\text { Stockley et al. (1997), Petersen \& Warner (1998) and Montgomerie } \\
\text { \& Fitzpatrick (2009) }\end{array}$ \\
\hline $\begin{array}{l}\text { Tanganyikan } \\
\text { cichlids }\end{array}$ & + & NA & NA & + & + & Balshine et al. (2001) and Fitzpatrick et al. (2009) \\
\hline Minnows & 0 & NA & NA & NA & NA & Pyron (2000) \\
\hline Seahorses & 0 & NA & NA & NA & NA & Kvarnemo \& Simmons (2004) \\
\hline Sharks & + & NA & NA & NA & NA & Fitzpatrick et al. (2012c) \\
\hline \multicolumn{7}{|l|}{$\begin{array}{l}\text { Reptiles and } \\
\text { amphibians }\end{array}$} \\
\hline Frogs & + & + & NA & + & NA & $\begin{array}{l}\text { Emerson (1997), Byrne et al. }(2002,2003) \text { and Prado \& Haddad } \\
\text { (2003) }\end{array}$ \\
\hline \multirow{2}{*}{\multicolumn{7}{|c|}{ Invertebrates }} \\
\hline & & & & & & \\
\hline Insects $^{\mathrm{a}}$ & NA & NA & NA & NA & + & Hunter \& Birkhead (2002) \\
\hline Butterflies & + & NA & NA & + & NA & Gage (1994) and Karlsson $(1995,1996)$ \\
\hline Moths & NA & NA & NA & + & NA & Morrow \& Gage (2000) \\
\hline $\begin{array}{l}\text { Eusocial ants } \\
\text { and bees }\end{array}$ & + & NA & NA & 0 & NA & Baer \& Boomsma (2004) and Fitzpatrick and Baer (2011) \\
\hline Bush crickets & + & NA & NA & NA & NA & Vahed et al. (2011) \\
\hline Beetles & + & NA & NA & NA & NA & Simmons et al. (2007b) \\
\hline Fireflies & + & NA & NA & NA & NA & Demary \& Lewis (2007) \\
\hline $\begin{array}{l}\text { Acanthocephalan } \\
\text { worms }\end{array}$ & - & NA & NA & NA & NA & Poulin \& Morand (2000) \\
\hline Nematodes & NA & NA & NA & + & NA & LaMunyon and Ward (1999) \\
\hline Drosophila & NA & NA & NA &,+ 0 & NA & $\begin{array}{l}\text { Pitnick (1996), Pitcher et al. (2005), Holman et al. (2008), Joly et al. } \\
\text { (2008) and Joly \& Schiffer (2010) }\end{array}$ \\
\hline
\end{tabular}

,+- , and 0 Indicates positive, negative, or no relationship, respectively, with sperm competition risk. NA indicates that the traits have not been examined. andicates studies with broad taxonomic coverage. 


\section{Strategic allocation of sperm}

Ejaculates are costly for males to manufacture, and males can become depleted of sperm and seminal fluid reserves with successive copulations, limiting the numbers of females they can mate with (Dewsbury 1982, Nakatsuru \& Kramer 1982, Birkhead \& Fletcher 1995, Olsson et al. 1997, Sirot et al. 2009). Within a species, therefore, males are expected to adjust how they allocate sperm during a given mating, depending on the reproductive returns expected for their investment, which will depend on female quality and male perceptions of sperm competition levels (Wedell et al. 2002, Parker \& Pizzari 2010). Specifically, males are expected to allocate more sperm when mating with high-quality females (to maximize genetic benefits) and previously mated females (to better contest sperm from rival males). However, within species predictions regarding male ejaculate expenditure under varying sperm competition levels are more complex. As the risk of sperm competition increases, males should increase ejaculate expenditure. However, the intensity of sperm competition is predicted to have an ameliorating effect on ejaculate expenditure, as the rate of fitness gain per unit investment in ejaculate production is expected to decline when more males are involved in the competition. Thus, male expenditure on their ejaculate is predicted to decline with increasing sperm competition intensity (Wedell et al. 2002, Parker \& Pizzari 2010).

Extensive attention has been devoted to assessing patterns of strategic sperm allocation across a broad range of taxa (reviewed by Wedell et al. (2002), Montgomerie \& Fitzpatrick (2009) and Parker \& Pizzari (2010)), and two recent meta-analyses have synthesized this diverse literature to provide a quantitative review of the general hypothesis that males strategically allocate their ejaculates (delBarco-Trillo 2011, Kelly \& Jennions 2011). These meta-analyses demonstrate that males consistently allocate more sperm to higher quality females (Kelly \& Jennions 2011) and when mating in the presence of a single competitor male (when the risk of sperm competition is elevated; delBarco-Trillo 2011, Kelly \& Jennions 2011). However, Kelly \& Jennions (2011) found no statistical support for the less frequently studied intensity models of sperm competition and, contrary to expectations, found that males allocate greater numbers of sperm to matings with virgin females. This mismatch with theoretical expectation may lie in our ability to manipulate the appropriate cues to sperm competition intensity. For example, studies often alter the number of males in the environment and assume that they are manipulating intensity cues, but from a male's perspective the presence of multiple rivals may signal greater risk rather than greater number of males actually competing for fertilizations (Engqvist \& Reinhold 2005). Studies that have manipulated a female's previous number of mating partners, and thus the true intensity of sperm competition, provide good support for the intensity models (Thomas \& Simmons 2008).

\section{Sperm quality and male fertility}

Sperm competition is also expected to influence the evolution of specific sperm traits, collectively referred to as sperm quality (Snook 2005), including sperm morphology (typically assessed using the length of the sperm head, midpiece, and flagellum), swimming speed, and viability (the proportion of live sperm in an ejaculate; Pizzari \& Parker 2009). A common technique used to infer selection acting on these sperm traits is to determine how they influence fertilization success under either noncompetitive and/or competitive scenarios. Although there is mixed evidence for which sperm traits are important in determining fertilization success, we can draw some tentative conclusions from the available evidence (summarized in Table 2). First, sperm morphology exhibits an inconsistent relationship with fertilization success, with some studies demonstrating that longer sperm are competitively superior, others that shorter sperm yield greater fertilization rates, and still others that find no effect of sperm length on fertilization success (Table 2). Interestingly, in competitive fertilizations, the negative relationships between sperm length and fertilization success are more prevalent in studies using natural matings, as opposed to artificial inseminations where sperm numbers are typically controlled experimentally. This raises the possibility that in these cases, trade-offs between sperm number and size influence competitive fertilization success. Secondly, the majority of studies that have examined sperm velocity have reported a positive relationship with fertilization success under both noncompetitive and competitive conditions (Table 2). Finally, the relationship between sperm viability and fertilization success is the least well characterized of the sperm traits assessed in Table 2. However, as several studies have reported a positive relationship between sperm viability and fertilization success, particularly under competitive fertilization conditions, it seems highly likely that sperm viability is indeed an important factor influencing fertilization success.

The literature summarized in Table 2 also reveals some interesting similarities and differences between how selection might operate based on the level of sperm competition and the mode of fertilization. For example, in internal fertilizing species, sperm morphology often determines fertilization success, although the effects reported are neither consistently positive nor negative. In contrast, for externally fertilizing species, there is little evidence that sperm morphology impacts fertilization success under either noncompetitive or competitive fertilization conditions. Faster swimming sperm appear to be competitively superior under noncompetitive and 
Table 2 The relationship between three commonly assessed sperm traits - sperm morphology, sperm velocity, and sperm viability - and fertilization success under i) noncompetitive and ii) competitive fertilizations. The method used in the fertilizations is classified as either natural matings (NM), where males and females mated without interference from the experimenter, or artificial inseminations (Al), which also includes IVFs, where sperm were experimentally introduced without matings taking place.

\begin{tabular}{|c|c|c|c|c|c|}
\hline \multirow[b]{2}{*}{ Species } & \multirow[b]{2}{*}{ Method } & \multicolumn{3}{|c|}{ Sperm traits } & \multirow[b]{2}{*}{ References } \\
\hline & & $\begin{array}{l}\text { Sperm } \\
\text { morphology }\end{array}$ & $\begin{array}{l}\text { Sperm } \\
\text { velocity }\end{array}$ & $\begin{array}{l}\text { Sperm } \\
\text { viability }\end{array}$ & \\
\hline \multicolumn{6}{|l|}{$\begin{array}{l}\text { (i) Non-competitive fertilizations } \\
\text { Internal fertilizers }\end{array}$} \\
\hline Domestic fowl (Gallus domesticus) & $\mathrm{Al}$ & NA & + & NA & Froman et al. (1999) \\
\hline Red deer (Cervus elaphus hispanicus) & $\mathrm{Al}$ & $+^{a}$ & + & NA & $\begin{array}{l}\text { Malo et al. (2005), Gomendio et al. (2007) and } \\
\text { Gomendio \& Roldan (2008) }\end{array}$ \\
\hline Horse (Equus ferus caballus) & $\mathrm{Al}$ & $+{ }^{a, b}$ & + & NA & Jasko et al. (1992) and Gravance et al. (1996) \\
\hline Human (Homo sapiens) & $\mathrm{Al}$ & $+^{a}$ & + & NA & $\begin{array}{l}\text { Marshburn et al. (1992), Barratt et al. (1993), } \\
\text { Krause (1995), Donnelly et al. (1998), } \\
\text { Shulman et al. (1998), Badawy et al. (2009) } \\
\text { and Youn et al. (2011) }\end{array}$ \\
\hline Rat (Rattus sp.) & $\mathrm{Al}$ & NA & + & NA & Moore \& Akhondi (1996) \\
\hline Boar (Sus scrofa) & $\mathrm{Al}$ &,$-+^{c, d}$ & $+^{c}$ & $+^{\mathrm{c}}$ & $\begin{array}{l}\text { Holt et al. (1997), Hirai et al. (2001) and } \\
\text { Sutkeviciene et al. (2009) }\end{array}$ \\
\hline Cricket (Teleogryllus oceanicus) & NM & NA & NA & 0 & García-González \& Simmons (2005a) \\
\hline \multicolumn{6}{|l|}{ External fertilizers } \\
\hline Walleye (Sander vitreus) & $\mathrm{Al}$ & 0 & + & NA & Casselman et al. (2006) \\
\hline Sea urchin (Lytechinus variegatus) & $\mathrm{Al}$ & NA & + & NA & Levitan (2000) \\
\hline Sea urchin (Anthocidaris crassispina) & $\mathrm{Al}$ & NA & + & NA & Au et al. (2002) \\
\hline Mussel (Mytilus galloprovincialis) & $\mathrm{Al}$ & - & - & NA & Fitzpatrick et al. (2012d) \\
\hline Frog (Crinia georgiana) & $\mathrm{Al}$ & 0 & 0 & 0 & Dziminski et al. (2010b) \\
\hline \multicolumn{6}{|l|}{ (ii) Competitive fertilizations } \\
\hline \multicolumn{6}{|l|}{ Internal fertilizers } \\
\hline Domestic fowl (Gallus domesticus) & $\mathrm{Al}$ & NA & $+{ }^{e}$ & NA & Birkhead et al. (1999) and Pizzari et al. (2008) \\
\hline Mallard (Anas platyrhynchos) & $\mathrm{Al}$ & 0 & + & NA & Denk et al. (2005) \\
\hline Swordtail (Xiphophorus helleri) & $\mathrm{Al}$ & 0 & + & NA & Gasparini et al. (2010) \\
\hline Swordtail (Xiphophorus nigrensis) & $\mathrm{Al}$ & NA & $-^{\mathrm{e}}$ & + & Smith (2012) \\
\hline Guppy (Poecilia reticulata) & $\mathrm{Al}$ & 0 & + & NA & Boschetto et al. (2011) \\
\hline Mice (Mus domesticus) & NM & - & NA & NA & Firman \& Simmons (2008b) \\
\hline Dung beetle (Onthophagus taurus) & NM & $-{ }^{f}$ & NA & NA & García-González \& Simmons (2007b) \\
\hline Fruit fly (Drosophila melanogaster) & NM & $+{ }^{f}$ & - & NA & $\begin{array}{l}\text { Miller \& Pitnick (2002), Pattarini et al. (2006) and } \\
\text { Lüpold et al. (2012) }\end{array}$ \\
\hline Cricket (Gryllus bimaculatus) & NM & $0,-$ & NA & NA & $\begin{array}{l}\text { Morrow \& Gage (2001) and Gage \& Morrow } \\
(2003)\end{array}$ \\
\hline Cricket (Teleogryllus oceanicus) & NM & 0 & NA & + & $\begin{array}{l}\text { Simmons et al. (2003) and García-González \& } \\
\text { Simmons }(2005 b)\end{array}$ \\
\hline Snail (Viviparus ater) & NM & $+^{\mathrm{g}}$ & NA & NA & Oppliger et al. (2003) \\
\hline Nematode (Caenorhabditis elegans) & NM & $+{ }^{\mathrm{h}}$ & + & NA & LaMunyon \& Ward (1998) \\
\hline Bulb mite (Rhizoglyphus robini) & NM & $-{ }^{h}$ & NA & NA & Radwan (1996) \\
\hline \multicolumn{6}{|l|}{ External fertilizers } \\
\hline Atlantic salmon (Salmo salar) & $\mathrm{Al}$ & 0 & + & NA & Gage et al. (2004) \\
\hline Arctic charr (Salvelinus alpinus) & $\mathrm{Al}$ & NA & + & NA & Liljedahl et al. (2008) \\
\hline Cod (Gadus morhua) & $\mathrm{Al}$ & NA & + & NA & Skjaeraasen et al. (2009) \\
\hline Frog (Crinia georgiana) & $\mathrm{Al}$ & 0 & - & 0 & Dziminski et al. (2009) \\
\hline
\end{tabular}

,+- , and 0 Indicates positive, negative, or no relationship, respectively, with fertilization success. NA indicates that the sperm trait has not

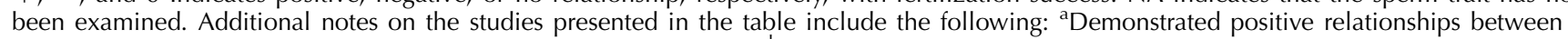
male fertility and the percentage of morphologically normal sperm. ${ }^{b}$ Sperm morphology was compared between stallions known to be either fertile or subfertile. ${ }^{C}$ Fertility measured as total litter size in multiparous females. ${ }^{d}$ Assessed sperm head morphology, including area and length. ${ }^{e}$ Effects are contingent on the time since insemination. ${ }^{f}$ Female reproductive tract dimensions may influence the relationship between sperm size and competitive fertilization success. ${ }^{g}$ Refers to length of non-fertilizing oligopyrene sperm, while fertilizing eupyrene sperm length did not influence competitive fertilization success. ${ }^{\text {h }}$ Refers to sperm size as these species have aflagellate sperm.

competitive fertilizations in a number of species and in both internal and external fertilizing species, despite the fundamental differences in the fertilization environments (Table 2). While these results may be suggestive, they should be treated with caution, as there are few cases of the same species and sperm traits being assessed under both fertilization conditions for us to draw any firm conclusions. For example, in crickets, sperm viability was found to be a significant determinant of competitive fertilization success (García-González \& Simmons 2005b) but not noncompetitive fertilization success (García-González \& 2005a). Similarly, in frogs, sperm swimming speed affected competitive (Dziminski et al. 2009) but not noncompetitive fertilization success 
(Dziminski et al. 2010b). Further investigations of sperm traits under both fertilization conditions in the same species may help to determine how selection acts on sperm traits for functional fertility (in noncompetitive fertilizations) compared with how selection operates on sperm traits during sperm competition.

\section{Evolution of sperm size and speed}

The available literature reviewed in Table 2 provides little evidence for a general pattern of selection acting on sperm size within species. Not surprisingly, therefore, extensive debate remains regarding how sperm competition influences the evolution of sperm size and the underlying relationship between sperm form and function. Sperm competition has alternatively been argued to influence sperm size in one of two ways. Under conditions where males gain a reproductive advantage by inseminating large numbers of sperm, and assuming that sperm number trade-offs against sperm size, increases in the levels of sperm competition are thought to favor the production of smaller sperm (Parker 1970, 1982). Recent comparative evidence suggests that such trade-offs between sperm size and number are more prevalent in species where fertilization follows a raffle mechanism rather than a sperm displacement mechanism (Immler et al. 2011). Alternatively, sperm competition has been argued to favor the evolution of larger sperm (Gomendio \& Roldan 1991), provided there is a positive relationship between sperm size and speed and faster sperm are competitively superior to slower sperm. While there is some evidence demonstrating that faster sperm are competitively superior (see Table 2), resolving the empirical and theoretical relationship between sperm size and speed has proven problematic (Humphries et al. 2008).

There is growing evidence of a relationship between sperm size and swimming speed across species (Table 1). For example, in a series of comparative studies, Gomendio \& Roldan et al. (1991, 2008), have repeatedly demonstrated that longer sperm swim faster among mammals (Montoto et al. 2011a, Tourmente et al. 2011a). Similarly, comparative studies in fishes (Fitzpatrick et al. 2009) and birds (Lüpold et al. 2009a but see Kleven et al. (2008)) have also demonstrated that larger sperm swim faster than smaller sperm. However, in contrast to the results from comparative studies, few within species studies have revealed a link between sperm size and speed (Humphries et al. 2008). Recently, Fitzpatrick et al. (2010) argued that a functional relationship between sperm size and speed may be masked by extensive within male variance in sperm traits and that a clear relationship between sperm size and speed was evident when assessing the covariance between these sperm traits at the level of the individual sperm cell. While further validation of Fitzpatrick et al.'s (2010) techniques accounting for within male variance in sperm traits across a broad range of species is certainly required, these preliminary findings suggest that a relationship between sperm size and speed may be more prevalent than currently thought and may offer an explanation for how sperm competition operates on sperm traits.

Despite the debate regarding how selection may act on sperm traits, a growing body of evidence suggests that sperm competition plays a major role in shaping the coevolution of sperm size and speed. Comparative studies across a broad range of taxa offer three compelling lines of evidence that sperm competition influences the coevolution of sperm size and speed (reviewed in Table 1). First, comparative studies in mammals, fishes, and birds have found that species experiencing greater levels of sperm competition have faster swimming and more motile sperm than species where sperm competition is relaxed or absent (Table 1). Secondly, phylogenetic reconstructions of sperm trait evolution in a group of well-studied cichlid fishes provided solid support for the role of sperm competition in shaping ejaculate traits, by revealing that evolutionary changes in mating behavior (and thus the level of sperm competition) occurred before evolutionary changes in sperm size and speed (Fitzpatrick et al. 2009). Finally, the majority of comparative studies performed over the past 20 years have reported positive relationships between the level of sperm competition and both flagellum and total sperm length (Table 1). However, studies reporting either negative relationships or no influence of sperm competition on these measures have prevented a clear picture from emerging (Gomendio \& Roldan 2008, Montgomerie \& Fitzpatrick 2009, Pitnick et al. 2009a). Similarly, no clear patterns are evident regarding how sperm competition influences the evolution of sperm head and midpiece lengths (Table 1). Recently, theoretical and empirical work posited a potential explanation for the ambiguity surrounding evolutionary responses in sperm size by suggesting that the relationships between sperm size and sperm competition may stem from trade-offs between how selection acts on sperm size and number in response to variation in the mechanisms regulating sperm competition (Parker et al. 2010, Immler et al. 2011).

Within species studies have also revealed complex and oftentimes contradictory evolutionary responses of sperm size and speed to sperm competition. Using experimentally evolving populations to contrast sperm traits in selection lines experiencing either high or low levels of sperm competition, studies in insects have demonstrated that sperm size is not influenced by selection history (Hosken \& Ward 2001, Pitnick et al. 2001). In mice, Mus musculus, sperm velocity and competitive fertilization success were increased in high sperm competition selection lines while sperm length remained unchanged (Firman \& Simmons 
2010a, 2010b). Similarly, in species with alternative reproductive tactics, relatively few studies have reported differences in sperm morphology between or among tactics while most studies report that sneaker males have faster swimming sperm than guarding males (Montgomerie \& Fitzpatrick 2009, Pitnick et al. 2009a). Finally, intriguing evidence that sperm competition influences sperm performance and morphology comes from studies demonstrating gamete plasticity in response to changing selective environments. For example, in the Arctic charr, Salvelinus alpinus, and fowl, Gallus gallus (Rudolfsen et al. 2006, Cornwallis \& Birkhead 2007), changes in social status resulted in changes in sperm velocity, with socially dominant males, who experience reduced levels of sperm competition, producing ejaculates in which sperm have reduced swimming speeds compared with socially subordinate males. In the swordtail Xiphophorus nigrensis, a species with alternative reproductive tactics, small sneaker males increased their sperm swimming speed when paired with other sneaker males (Smith \& Ryan 2011). These changes in sperm velocity occurred rapidly: over 3 days in Arctic charr, 7 days in $X$. nigrensis, and 2 weeks in fowl. Over a slightly longer time frame ( $\sim 1$ month), following experimental manipulation of adult densities in the broadcast spawning ascidian Styela plicata, males experimentally allocated to high-density treatment groups, where sperm competition is more likely, produced longer and more motile sperm that swam for longer periods of time than did males in low-density treatment groups (Crean \& Marshall 2008). Finally, in the Gouldian finch, Erythrura gouldiae, changes in social environment that reflect changes in the levels of sperm competition led to changes in sperm midpiece and flagellum lengths (Immler et al. 2010).

\section{Variation in sperm morphology}

Persistent directional selection is expected to erode variance in sperm morphology, generating a single optimal sperm phenotype that maximizes competitive fertility (Parker 1993, Parker \& Begon 1993, Birkhead et al. 2005). Indeed, several comparative studies in birds have found that sperm are morphologically less variable in species where the level of sperm competition is greater (Calhim et al. 2007, Immler et al. 2008, Kleven et al. 2008, Lüpold et al. 2009b). These studies provide support for the notion that sperm morphology is under strong selection from sperm competition. However, reductions in sperm variance in response to sperm competition may be due to either selection for improved sperm production efficiency, leading to a reduction in developmental errors (Hunter \& Birkhead 2002), or a reduction in genomic conflict between the evolutionary interests of the haploid sperm and the diploid male (Parker 1993, Parker \& Begon 1993, Immler et al. 2008, Pizzari \& Foster 2008). Unfortunately, distinguishing between these two, though not mutually exclusive, hypotheses can be challenging. To overcome this challenge, Fitzpatrick \& Baer (2011) assessed how sperm competition influences sperm length variation in eusocial ants and bees, where haploid males produce sperm that do not experience haploid-diploid genomic conflict. They found that variation in sperm length was negatively associated with the level of sperm competition. Because variation in sperm morphology cannot be explained by genomic conflict in these eusocial insects, these results suggest that selection is acting on sperm production machinery to improve sperm quality in response to increased sperm competition.

Despite the apparent evolution of sperm toward a single optimal phenotype, variation in morphology can persist. Some level of variation might always be present within an ejaculate simply because random developmental errors will occur during sperm production. However, Calhim et al. (2011) recently offered an alternative explanation for how sperm variance might be maintained in an interesting study of a natural population of the highly promiscuous superb fairywren (Malurus cyaneus). Calhim et al. (2011) found that males with sperm composed of a short flagellum and relatively long head had greater reproductive success when mating in the disfavored role of the cuckold, while males with sperm composed of a long flagellum and relatively short head secured more paternity with their social partner by preventing cuckoldry. Such opposing patterns of selection on sperm morphology depending on male mating roles may help to explain the maintenance of variation in sperm morphology despite selection aimed at eroding this variance.

In addition to maintaining variation in sperm length, selection for different sperm phenotypes under different competitive situations could ultimately favor the evolution of distinct sperm morphologies. Indeed, there are many examples of species that produce heteromorphic sperm, which in animals typically results in the production of both fertile and non-fertile sperm morphs (Till-Bottraud et al. 2005). There is evidence from insects that non-fertilizing sperm morphs can control female remating rates (Cook \& Wedell 1999) and protect fertilizing sperm from immunological attack from the female's reproductive tract (Holman \& Snook 2008). However, by and large, the adaptive significance of sperm heteromorphism is poorly understood and deserves further study.

\section{Sperm cooperation}

Cooperation among sperm within a given male's ejaculate is another exciting area of research in sperm competition that deserves greater attention (Pizzari \& Foster 2008, Higginson \& Pitnick 2010). In a variety of species, sperm can form conjugates of two or more individuals, who collectively swim faster than can 
individual sperm (Hayashi 1998, Moore et al. 2002, Fisher \& Hoekstra 2010). Among carabid ground beetles, the size of sperm bundles increases with traits known to be subject to selection from sperm competition, such as postcopulatory mate guarding and genital complexity (Takami \& Sota 2007). In muroid rodents, the characteristic hooked morphology of the sperm head can be involved in the production of sperm conjugates, and the curvature of the hook increases with testes size, a widely used proxy for the strength of selection from sperm competition, suggesting that sperm conjugation may be an evolutionary response to selection via sperm competition in this group (Immler et al. 2007a). Nonetheless, experimental evolution failed to find divergence in the curvature of the sperm hook among populations of house mice experiencing variation in the strength of selection from sperm competition (Firman \& Simmons 2009, Firman et al. 2011). The evolution of cooperation among sperm in the race to fertilize ova will depend strongly on whether sperm are under individual haploid control or whether they are controlled by the diploid male producing them (Immler 2008, Pizzari \& Foster 2008, Higginson \& Pitnick 2010).

\section{The evolution of sperm viability}

Owing to the relatively paucity of studies, it is currently not possible to draw broad conclusions regarding how sperm viability is influenced by variation in the level of sperm competition. However, there is some evidence that sperm viability influences competitive fertilization success (see Table 2). Importantly, the comparative studies reviewed in Table 1 reveal that polyandrous insect species have more viable sperm than closely related monandrous species (Hunter \& Birkhead 2002) and that sperm viability is positively associated with sperm competition among Australian wrens (Rowe \& Pruett-Jones 2011). More studies that explore responses to selection on sperm viability are required.

\section{Seminal fluid proteins: the neglected weaponary}

Despite the considerable volume of research that has focused on how selection acts on testes size and sperm production, and sperm form and function, researchers often neglect the critical role that seminal fluids play in imparting motility and fertilization capacity to sperm. Sperm are delivered from the male, bathed in a complex soup of proteins that are derived from the male accessory glands. Seminal fluid proteins (sfps) play a role in the nourishment, protection, capacitation, and motility of sperm within the female reproductive tract and should therefore be expected to contribute to a male's fertilization success (Poiani 2006). In humans, for example, seminogelin I and seminogelin II inhibit sperm motility, while seminal fluid proteases cleave seminogelins after ejaculation, promoting the rapid onset of motility in the female tract (Veveris-Lowe et al. 2007). Fertilization-promoting peptide stimulates sperm penetration abilities and thus promotes fertilization (Fraser \& Osiguwa 2004), and the glutathione peroxidase family protect sperm from oxidative damage by reactive oxygen species (Drevet 2006). The function of sfps has been the subject of considerable research focus in the Drosophila model system. Here, protein secretions from the male accessory glands contribute to the seminal fluid and have been found to play major roles in the movement of sperm through and storage in the female reproductive tract, the competitive fertilization success of a male's sperm, the future receptivity of females to remating, and female investment in oviposition (Ram \& Wolfner 2007). Given its critical influence, both on sperm performance and on the interactions between sperm and egg at the time of fertilization (Clark et al. 2006), seminal fluid productivity and function are expected to evolve in response to sperm competition.

\section{The evolution of male reproductive accessory glands}

The male reproductive accessory glands are the principle sites for the manufacture and secretion of sfps. As with testes, there is now good evidence that male expenditure on accessory glands does evolve in response to sperm competition. A comparative analysis of male reproductive anatomy among rodent species found a positive association between the strength of selection from sperm competition and the size of the seminal vesicles and the anterior prostate, two male reproductive accessory glands that contribute proteins to the seminal fluid (Ramm et al. 2005). In Drosophila melanogaster, laboratory evolution studies have shown that accessory gland productivity responds to variation in selection from sperm competition (Linklater et al. 2007). Thus, Linklater et al. established populations of flies with either a male-biased or female-biased sex ratio. The probability that females will encounter and mate with multiple males and thus the strength of selection from sperm competition was assumed to be greater in populations with a male biased sex ratio. After more than 60 generations of laboratory evolution, accessory glands evolved greater productivity in male-biased populations compared with populations with a femalebiased sex ratio (Linklater et al. 2007). Similar findings were obtained in a study of Drosophila pseudoobscura in which the strength of selection from sperm competition was manipulated by either enforcing monogamy or controlling the degree to which females could mate polyandrously (Crudgington et al. 2009). Interestingly, testes size did not respond to variation in selection from sperm competition in either of these experiments, suggesting that in Drosophila seminal fluids may play an even more important role in 
determining competitive fertilization success than does the number of sperm a male can produce. Molecular research is now revealing how individual sfps evolve in response to sperm competition.

\section{The evolution of sfps}

At the molecular level, the signature of positive selection can be recognized from a comparison of the rate of non-synonymous to synonymous $(\mathrm{dN} / \mathrm{dS}$ ) nucleotide substitutions in the DNA that encodes a given protein (Goldman \& Yang 1994). Non-synonymous substitutions change an amino acid while synonymous substitutions do not. Because dS provides an estimate of the neutral rate of nucleotide substitution, a ratio of $\mathrm{dN} / \mathrm{dS}>1$ indicates a selective advantage to amino acid substitutions in a protein that results in adaptive divergence. Reproductive proteins facilitate three fundamental stages of reproduction; the transit of sperm through and capacitation within the female genital tract, the storage and survival of sperm before egg release, and the interactions between sperm and egg that culminate in successful fertilization (Clark et al. 2006). Genes that encode reproductive proteins involved at each of these stages appear to have evolved more rapidly than other genes. Thus, genome screens from taxa ranging from gastropods (Metz et al. 1998) to insects (Haerty et al. 2007) and mammals (Clark \& Swanson 2005) show that reproductive proteins have substitution ratios $>1$ and are among the most evolutionarily divergent proteins known.

There is good evidence that sexual selection via sperm competition has been instrumental in the evolutionary divergence of sfps. In house mice, the seminal vesicle protein gene Pate4 (SvS7) is evolving particularly rapidly (Karn et al. 2008), as is Svs2 (Ramm et al. 2009). Moreover, the ratio $\mathrm{dN} / \mathrm{dS}$ for Svs2 is positively associated with the strength of selection from sperm competition across rodent species. Seminal vesicle proteins are involved in the formation of the mating plug, the size of which is also associated with the strength of selection from sperm competition (Ramm et al. 2005). Mating plugs are thought to play a role in the prevention of mating by, and thus sperm competition from, rival males (Simmons 2001). In primates, the SEMG2 gene product is a major structural component of the semen coagulum and also shows positive selection as indicated by a high ratio of $\mathrm{dN} / \mathrm{dS}$. The rate of evolution of SEMG2 also correlates with the levels of female promiscuity, as does the firmness of the semen coagulum (Dorus et al. 2004). These studies strongly suggest that in primates too, sfps involved in the formation of mating plugs are under positive selection from sperm competition. Evidence for a role of sperm competition in protein evolution also comes from studies of Drosophila. Here too accessory gland genes show evidence of strong positive selection (Haerty et al. 2007), and accessory gland protein divergence is greater in lineages of Drosophila with greater postmating sexual selection (Wagstaff \& Begun 2007).

It seems we know much about sfps and their function. However, to place these studies in context, for Drosophila, the number of newly discovered sfps is rising almost exponentially. At last count, $133 \mathrm{sfps}$ had been detected, with just a handful of these having known function (Chapman 2008, Findlay et al. 2008). In mice, 69 sfps have been identified from the female reproductive tract following mating (Dean et al. 2011), while in humans, 923 sfps have been found (Pilch \& Mann 2006), but again only in a very limited number of cases are the functions of individual proteins known. The exploration of sfps and their functional significance is in its infancy but promises to shed light on the functional mechanisms underlying sperm competitiveness.

\section{Strategic adjustments in seminal fluid composition}

Much research has explored male responses to sperm competition in terms of the numbers of sperm ejaculated (reviewed earlier). However, there are a growing number of studies that suggest the quality of those sperm may also be adjusted in an adaptive manner. Work with field crickets, Teleogryllus oceanicus, has shown how the viability of sperm in the ejaculate varies with a male's perceptions of sperm competition (Simmons et al. 2007a, Thomas \& Simmons 2007). In these insects, males appear able to detect not just the mating status of a female, be she mated or unmated, but also the number of males she has accepted, based on chemical cues left by males during copulation. Thus, when the perceived risk of sperm competition is elevated, males will produce ejaculates containing sperm of higher viability, but as the number of males competing for fertilizations is increased beyond two males, so that the payoff from a given male's investment in his ejaculate declines, males produce ejaculates containing sperm of decreasing viability (Simmons et al. 2007a, Thomas \& Simmons 2007). Research on humans (Kilgallon \& Simmons 2005), feral fowl (Cornwallis \& Birkhead 2007), and fish (Smith \& Ryan 2011) point to strategic adjustments in sperm quality with risk of sperm competition; in these cases, males ejaculate sperm with faster swimming speeds when they perceive a threat from rival males, or with females of greater reproductive value. However, these studies beg the question of how males adjust the quality of their sperm? The most likely candidate would appear to be adjustments in seminal fluid. Because gene transcription is apparently absent in sperm cells, their functionality is largely dependent on post-translational modifications to their protein compliment that are brought about by sfps. Sfps are known to influence the viability of sperm (den Boer et al. 2008, Holman 2009, Simmons \& Beveridge 2011) and their motility (Lindholmer 1974, Poiani 2006). In some insect species, 
seminal fluid has been implicated in the killing of sperm present from rival males (Fry \& Wilkinson 2004, den Boer et al. 2010), and it has even been suggested that males might exploit the expenditure on sfps made by their rivals, for example, if sfps buffered the female reproductive tract against spermicidal secretions (Hodgson \& Hosken 2006). Seminal fluid may be more costly to produce than sperm themselves (Simmons 2001), so that males might be expected to allocate these costly secretions to their ejaculates, depending on the levels of sperm competition.

Recent attempts have been made to model the evolution of male allocation to sfps within Parker's sperm competition game framework. Cameron et al. (2007) considered the case where sfps act to increase the competitive ability or fertilization capacity of the sperm contained within the ejaculate. Their game theoretic analyses did indeed predict that males should invest more on sfps than sperm under these conditions. Moreover, in some species, sfps can contribute to female fitness through their contributions to egg production and/or offspring development (Simmons 2001, García-González \& Simmons 2007a). Theoretical models predict that male fitness could be enhanced by withholding these beneficial sfps from females with whom the risk of lost paternity through sperm competition is high (Cameron et al. 2007, Alonzo \& Pizzari 2010). Despite these first prospective attempts to model the evolutionary dynamics of seminal fluid investments made by males, few studies have attempted to examine whether males can vary the composition of their seminal fluid in an adaptive manner.

In bank voles, Myodes glareolus, males exposed to the odors of rival males during their development invested more in the growth of their seminal vesicles, the glands responsible for sfps that contribute to the mating plug, than did males with only limited exposure to rivals (Lemaître et al. 2011). In fowl, changes in seminal fluid quality have been implicated in the elevated motility of sperm when males copulate with high-quality females (Cornwallis \& O'Conner 2009). The seminal fluid of D. melanogaster contains a cocktail of more than 130 proteins that are gradually being isolated and characterized (Findlay et al. 2008). One protein known to be important in sperm competition is sex peptide, which suppresses female sexual receptivity following mating so that males avoid sperm competition from future rivals (Liu \& Kubli 2003). Seminal fluid also contains ovulin, a protein that stimulates an immediate elevation in egg production and oviposition by the mated female (Herndon \& Wolfner 1995). As noted earlier, experimental evolution under elevated levels of sperm competition results in responses to accessory gland size and productivity (Linklater et al. 2007), and in particular productivity of sex peptide (Wigby et al. 2009). Male flies exposed to potential rivals during copulation will copulate for longer and transfer larger quantities of both sex peptide and ovulin (Wigby et al. 2009). What is even more remarkable is that males appear able to tailor their seminal fluid composition to a particular mating event. Thus, when mating with a virgin female, males will transfer relatively more ovulin than when mating with a previously mated female, presumably because oviposition has already been induced by the female's previous mating partner (Sirot et al. 2011). Such strategic adjustments in fecundity enhancing sfps are consistent with the predictions arising from game theoretic modeling of male ejaculate expenditure (Cameron et al. 2007, Alonzo \& Pizzari 2010).

\section{Future directions}

There is now overwhelming evidence that sperm competition has been an influential agent in the evolution of male reproductive biology. Comparative studies across species of a wide range of taxa, from parasitic worms to primates, consistently support the expectation that sperm competition should favor increased male investment in testicular tissue and sperm production; multiple mating by females drives the evolution of increased competitive fertility. However, previous research has focused predominantly on sperm numbers. We are only now beginning to examine features of the sperm themselves, and our findings are often equivocal. Sperm morphology is sometimes associated with swimming performance and sometimes not. We feel the problem here is a lack of consideration of the ejaculate as an integrated unit. All else being equal, perhaps sperm length should increase swimming speed. However, all else is rarely equal. Sperm motility is influenced by the selective environment in which it operates (i.e. internal vs external fertilization, sensu Humphries et al. (2008)) and is critically dependent on sfps contained within the ejaculate. We have discussed studies that show increased swimming performance in response to sperm competition, in the absence of increased sperm length, and it is possible that changes in competitive male fertility can be achieved by alternative routes, either via changes in sperm morphology, seminal fluid chemistry, or both. Such a scenario would add considerable noise to any attempt to find general patterns of evolutionary change in sperm morphology across taxa. We argue that it is time to begin to consider the ejaculate as an integrated functional unit and to assess the fitness of whole ejaculates in a multivariate analytical framework (Fitzpatrick et al. $2012 d$ ). Only then will we reveal the relative importance of individual traits (sperm number, morphology, and function, seminal fluid composition, etc.) to male fertility and to identify trade-offs that might occur between these individual ejaculate traits. Importantly, in this review, we have focused on sperm wars between males. Females can have a considerable selective impact on fertilization success, via the mechanisms of cryptic 
female choice that determine the number of sperm in competition, their motility, and fertilization capacity (Eberhard 1996, Simmons 2001, Ball \& Parker 2003, Humphries et al. 2008, Pitnick et al. 2009b). Incorporating female effects into multivariate approaches will also be necessary.

We also envisage exciting future developments in sperm competition research. It is not sufficient for sperm simply to arrive at the ova before those of other males. We expect that selection will act on the mechanisms that make sperm fertilization-competent. Indeed, recent work on four closely related rodent species has found that the males of species with higher levels of polyandry produce ejaculates containing a greater proportion of sperm that undergo capacitation and a greater proportion of sperm that respond to progesterone, an ovum-associated signal (Gomendio et al. 2006). Sperm competition thus appears to favor the evolution of fertilization competency. Future studies, both within and between species, that focus on the fertilization process itself will be of great interest. Research on sfps illustrate the power of studies at the genomic level, and future work on the expression of sperm genes is likely also to be revealing. For example, studies of genes in the genus Mus suggest that high divergence in promoters of the gene protamine 2 is associated with selection from sperm competition (Martin-Coello et al. 2009). These genes control the packaging of DNA in the sperm head, subsequent head dimensions, and sperm swimming speed. We believe that modern genomic approaches such as these will not only enhance our understanding of the evolutionary consequences of sperm competition for ejaculate form and function but will also provide us with the knowledge of what makes a male fertile, knowledge that can be brought to bare on real-world problems of male fertility and infertility.

\section{Declaration of interest}

The authors declare that there is no conflict of interest that could be perceived as prejudicing the impartiality of the review reported.

\section{Funding}

L W Simmons was supported by an Australian Professorial Fellowship and J L Fitzpatrick was supported by an Australian Postdoctoral Fellowship from the Australian Research Council.

\section{References}

Alonzo SH \& Pizzari T 2010 Male fecundity stimulation: conflict and cooperation within and between the sexes: model analyses and coevolutionary dynamics. American Naturalist 175 174-185. (doi:10.1086/649596)

Anderson MJ \& Dixon AF 2002 Motility and the mid-piece. Nature 416496. (doi:10.1038/416496a)
Anderson MJ, Nyholt J \& Dixon AF 2005 Sperm competition and the evolution of sperm midpiece volume in mammals. Journal of Zoology 267 135-142. (doi:10.1017/S0952836905007284)

Arnqvist G \& Nilsson T 2000 The evolution of polyandry: multiple mating and female fitness in insects. Animal Behaviour 60 145-164. (doi:10. 1006/anbe.2000.1446)

Au DWT, Chiang MWL, Tang JYM, Yuen BBH, Wang YL \& Wu RSS 2002 Impairment of sea urchin sperm quality by UV-B radiation: predicting fertilization success from sperm motility. Marine Pollution Bulletin $\mathbf{4 4}$ 583-589. (doi:10.1016/S0025-326X(01)00288-0)

Badawy A, Elnashar A \& Eltotongy M 2009 Effect of sperm morphology and number on success of intrauterine insemination. Fertility and Sterility $\mathbf{9 1}$ 777-781. (doi:10.1016/j.fertnstert.2007.12.010)

Baer B \& Boomsma JJ 2004 Male reproductive investment and queen mating-frequency in fungus growing ants. Behavioral Ecology $\mathbf{1 5}$ 426-432. (doi:10.1093/beheco/arh025)

Ball MA \& Parker GA 2003 Sperm competition games: sperm selection by females. Journal of Theoretical Biology 224 27-42. (doi:10.1016/S00225193(03)00118-8)

Balshine S, Leach BJ, Neat F, Werner NY \& Montgomerie R 2001 Sperm size of African cichlids in relation to sperm competition. Behavioral Ecology 12 726-731. (doi:10.1093/beheco/12.6.726)

delBarco-Trillo J 2011 Adjustment of sperm allocation under high risk of sperm competition across taxa: a meta-analysis. Journal of Evolutionary Biology 24 1706-1714. (doi:10.1111/j.1420-9101.2011.02293.x)

Barratt CLR, Tomlinson MJ \& Cooke ID 1993 Prognostic significance of computerized motility analysis for in vivo fertility. Fertility and Sterility $\mathbf{6 0}$ 520-525.

Bateman AJ 1948 Intrasexual selection in Drosophila. Heredity 2 349-368. (doi:10.1038/hdy.1948.21)

Birkhead TR \& Fletcher F 1995 Depletion determines sperm numbers in male zebra finches. Animal Behaviour 49 451-456. (doi:10.1006/anbe. 1995.0058)

Birkhead TR \& Møller AP 1998 Sperm Competition and Sexual Selection. London: Academic Press.

Birkhead TR, Martinez JG, Burke T \& Froman DP 1999 Sperm mobility determines the outcome of sperm competition in the domestic fowl. Proceedings of the Royal Society of London. Series B: Biological Sciences 266 1759-1764. (doi:10.1098/rspb.1999.0843)

Birkhead TR, Pellatt EJ, Brekke P, Yeates R \& Castillo-Juarez H 2005 Genetic effects on sperm design in the zebra finch. Nature 434 383-387. (doi:10.1038/nature03374)

den Boer SPA, Boomsma JJ \& Baer B 2008 Seminal fluid enhances sperm viability in the leafcuter ant Atta colombica. Behavioral Ecology and Sociobiology 62 1843-1850. (doi:10.1007/s00265-008-0613-5)

den Boer SPA, Baer B \& Boomsma JJ 2010 Seminal fluid mediates ejaculate competition in social insects. Science 327 1506-1509. (doi:10.1126/ science.1184709)

Boschetto C, Gasparini C \& Pilastro A 2011 Sperm number and velocity affect sperm competition success in the guppy (Poecilia reticulata). Behavioral Ecology and Sociobiology 65 813-821. (doi:10.1007/ s00265-010-1085-y)

Breed WG \& Taylor J 2000 Body mass, testes mass, and sperm size in murine rodents. Journal of Mammology 81 758-768. (doi:10.1644/1545$1542(2000) 081<0758:$ BMTMAS > 2.3.CO;2)

Briskie JV \& Montgomerie R 1992 Sperm size and sperm competition in birds. Proceedings of the Royal Society of London. Series B: Biological Sciences 247 89-95. (doi:10.1098/rspb.1992.0013)

Bryja J, Patzenhauerová H, Albrecht T, Mosansky L, Stanko M \& Stopka P 2008 Varying levels of female promiscuity in four Apodemus mice species. Behavioral Ecology and Sociobiology 63 251-260. (doi:10.1007/s00265-008-0656-7)

Byrne PG, Roberts JD \& Simmons LW 2002 Sperm competition selects for increased testes mass in Australian frogs. Journal of Evolutionary Biology 15 347-355. (doi:10.1046/j.1420-9101.2002.00409.x)

Byrne PG, Simmons LW \& Roberts JD 2003 Sperm competition and the evolution of gamete morphology in frogs. Proceedings of the Royal Society of London. Series B: Biological Sciences 270 2079-2086. (doi:10.1098/rspb.2003.2433)

Calhim S \& Birkhead TR 2007 Testes size in birds: quality versus quantity assumptions, errors, and estimates. Behavioral Ecology 18 271-275. (doi:10.1093/beheco/arl076) 
Calhim S, Immler S \& Birkhead TR 2007 Postcopulatory sexual selection is associated with reduced variation in sperm morphology. PLOS ONE 2 e413. (doi:10.1371/journal.pone.0000413)

Calhim S, Double MC, Margraf N, Birkhead TR \& Cockburn A 2011 Maintenance of sperm variation in a highly promiscuous wild bird. PLoS ONE 6 e28809. (doi:10.1371/journal.pone.0028809)

Cameron E, Day T \& Rowe L 2007 Sperm competition and the evolution of ejaculate composition. American Naturalist 169 E158-E172. (doi:10. 1086/516718)

Carter RV 1985 Testis size in sandpipers: the fertilization frequency hypothesis. Naturwissenschaften 72 157-158. (doi:10.1007/BF00 490407)

Casselman SJ, Schulte-Hostedde AI \& Montgomerie R 2006 Sperm quality influences male fertilization success in walleye (Sander vitreus). Canadian Journal of Fisheries and Aquatic Sciences 63 2119-2125. (doi:10.1139/f06-108)

Chapman T 2008 The soup in my fly: evolution, form and function of seminal fluid proteins. PLoS Biology 6 e179. (doi:10.1371/journal.pbio. 0060179)

Clark NL \& Swanson WJ 2005 Pervasive adaptive evolution in primate seminal proteins. PLoS Genetics 1 e35. (doi:10.1371/journal.pgen. 0010035)

Clark NL, Aagaard JE \& Swanson WJ 2006 Evolution of reproductive proteins from animals and plants. Reproduction 131 11-22. (doi:10. 1530/rep.1.00357)

Coker CR, McKinney F, Hays H, Briggs SV \& Cheng KM 2002 Intromittent organ morphology and testis size in relation to mating system in waterfowl. Auk 119 403-413. (doi:10.1642/0004-8038(2002)119[0403: IOMATS]2.0.CO;2)

Cook PA \& Wedell N 1999 Non-fertile sperm delay female remating. Nature 397 486. (doi:10.1038/17257)

Cornwallis CK \& Birkhead TR 2007 Changes in sperm quality and numbers in response to experimental manipulation of male social status and female attractiveness. American Naturalist 170 758-770. (doi:10.1086/ 521955)

Cornwallis CK \& O'Conner EA 2009 Sperm: seminal fluid interactions and the adjustment of sperm quality in relation to female attractiveness. Proceedings of the Royal Society of London. Series B: Biological Sciences 276 3467-3475. (doi:10.1098/rspb.2009.0807)

Crean AJ \& Marshall DJ 2008 Gamete plasticity in a broadcast spawning marine invertebrate. PNAS 105 13508-13513. (doi:10.1073/pnas. 0806590105)

Crudgington HS, Fellows S, Badcock NS \& Snook RR 2009 Experimental manipulation of sexual selection promotes greater male mating capacity but does not alter sperm investment. Evolution 63 926-938. (doi:10. 1111/j.1558-5646.2008.00601.x)

Dean MD, Findlay GD, Hoopman MR, Wu CC, MacCoss MJ, Swanson WJ \& Nachman MW 2011 Identification of ejaculated proteins in the house mouse (Mus domesticus) via isotopic labeling. BMC Genomics 12306. (doi:10.1186/1471-2164-12-306)

Demary KC \& Lewis SM 2007 Male reproductive allocation in fireflies (Photinus spp.). Invertebrate Biology 126 74-80. (doi:10.1111/j.17447410.2007.00078.x)

Denk AG, Holzmann A, Peters A, Vermeirssen ELM \& Kempenaers B 2005 Paternity in mallards: effects of sperm quality and female sperm selection for inbreeding avoidance. Behavioral Ecology 16 825-833. (doi:10. 1093/beheco/ari065)

Dewsbury DA 1982 Ejaculate cost and male choice. American Naturalist 119 601-610. (doi:10.1086/283938)

Donnelly ET, Lewis SEM, McNally JA \& Thompson W 1998 In vitro fertilization and pregnancy rates: the influence of sperm motility and morphology on IVF outcome. Fertility and Sterility 70 305-314. (doi:10. 1016/S0015-0282(98)00146-0)

Dorus S, Evans PD, Wyckoff GJ, Choi SS \& Lahn BT 2004 Rate of molecular evolution of the seminal protein gene SEMG2 correlates with levels of female promiscuity. Nature Genetics 36 1326-1329. (doi:10.1038/ ng1471)

Drevet JR 2006 The antioxidant glutathione peroxidase family and spermatozoa: a complex story. Molecular and Cellular Endocrinology 250 70-79. (doi:10.1016/j.mce.2005.12.027)
Dunn PO, Whittingham LA \& Hill GE 2001 Mating systems, sperm competition, and the evolution of sexual dimorphism in birds. Evolution 55 161-175.

Dziminski MA, Roberts JD, Beveridge M \& Simmons LW 2009 Sperm competitiveness in frogs: slow and steady wins the race. Proceedings of the Royal Society of London. Series B: Biological Sciences 276 3955-3961. (doi:10.1098/rspb.2009.1334)

Dziminski MA, Roberts JD, Beveridge M \& Simmons LW 2010a Amongpopulation covariation between sperm competition and ejaculate expenditure in frogs. Behavioral Ecology 21 322-328. (doi:10.1093/ beheco/arp191)

Dziminski MA, Roberts JD \& Simmons LW 2010b Sperm morphology, motility, and fertilization capacity in the myobatrachid frog Crinia georgiana. Reproduction, Fertility, and Development 22 516-522. (doi:10.1071/RD09124)

Eberhard WG 1996 Female Control: Sexual Selection by Cryptic Female Choice. Princeton: Princeton University Press.

Emerson SB 1997 Testis size variation in frogs: testing the alternatives. Behavioral Ecology and Sociobiology 41 227-236. (doi:10.1007/ s002650050383)

Engqvist L \& Reinhold K 2005 Pitfalls in experiments testing predictions from sperm competition theory. Journal of Evolutionary Biology 18 116-123. (doi:10.1111/j.1420-9101.2004.00792.x)

Findlay GD, Yi X, MacCoss MJ \& Swanson WJ 2008 Proteomics reveals novel Drosophila seminal fluid proteins transferred at mating. PLoS Biology 6 e178. (doi:10.1371/journal.pbio.0060178)

Firman RC \& Simmons LW 2008a The frequency of multiple paternity predicts variation in testes size among island populations of house mice. Journal of Evolutionary Biology 21 1524-1533. (doi:10.1111/j.14209101.2008.01612.x)

Firman RC \& Simmons LW 2008b Polyandry, sperm competition, and reproductive success in mice. Behavioral Ecology 19 695-702. (doi:10. 1093/beheco/arm158)

Firman RC \& Simmons LW 2009 Sperm competition and the evolution of the sperm hook in house mice. Journal of Evolutionary Biology 22 2505-2511. (doi:10.1111/j.1420-9101.2009.01867.x)

Firman RC \& Simmons LW 2010a Experimental evolution of sperm competitiveness in a mammal. BMC Evolutionary Biology 1119 (doi:10.1186/1471-2148-1111-1119).

Firman RC \& Simmons LW $2010 b$ Experimental evolution of sperm quality via postcopulatory sexual selection in house mice. Evolution 64 1245-1256. (doi:10.1111/j.1558-5646.2009.00894.x)

Firman RC, Cheam LY \& Simmons LW 2011 Sperm competition does not influence sperm hook morphology in selection lines of house mice. Journal of Evolutionary Biology 24 856-862. (doi:10.1111/j.1420-9101. 2010.02219.x)

Fisher HS \& Hoekstra HE 2010 Competition drives cooperation among related sperm of deer mice. Nature 463 801-803. (doi:10.1038/ nature08736)

Fitzpatrick JL \& Baer B 2011 Polyandry reduces sperm length variation in social insects. Evolution 65 3006-3012. (doi:10.1111/j.1558-5646. 2011.01343.x)

Fitzpatrick JL, Montgomerie R, Desjardins JK, Stiver KA, Kolm N \& Balshine S 2009 Female promiscuity promotes the evolution of faster sperm in cichlid fishes. PNAS 106 1128-1132. (doi:10.1073/pnas. 0809990106

Fitzpatrick JL, García-González F \& Evans JP 2010 Linking sperm length and velocity: the importance of intramale variation. Biology Letters 6 797-799. (doi:10.1098/rsbl.2010.0231)

Fitzpatrick JL, Almbro M, Gonzalez-Voyer A, Hamada S, Pennington C, Scanlan J \& Kolm N 2012a Sexual selection uncouples the evolution of brain and body size in pinnipeds. Journal of Evolutionary Biology 25 1321-1330. (doi:10.1111/j.1420-9101.2012.02520.x)

Fitzpatrick JL, Almbro M, Gonzalez-Voyer A, Kolm N \& Simmons LW $2012 b$ Male contest competition and the coevolution of weaponry and testes in pinnipeds. Evolution (doi:10.1111/j.1558-5646.2012. 01713.x)

Fitzpatrick JL, Kempster R, Daly-Engel TS, Collin SP \& Evans JP 2012C Assessing the potential for postcopulatory sexual selection in elasmobranchs. Journal of Fish Biology 80 1141-1158. 
Fitzpatrick JL, Simmons LW \& Evans JP 2012d Complex patterns of multivariate selection on the ejaculate of a broadcast spawning marine invertebrate. Evolution 66 2451-2460. (doi:10.1111/j.1558-5646.2012. 01627.x)

Fraser LR \& Osiguwa OO 2004 Human sperm responses to calcitonin, angiotensin II and fertilization-promoting peptide in prepared semen samples from normal donors and infertility patients. Human Reproduction 19 596-606. (doi:10.1093/humrep/deh126)

Froman DP \& Feltmann AJ 1998 Sperm mobility: a quantitative trait of the domestic fowl (Gallus domesticus). Biology of Reproduction 58 379-384. (doi:10.1095/biolreprod58.2.379)

Froman DP, Feltmann AJ, Rhoads ML \& Kirby JD 1999 Sperm mobility: a primary determinant of fertility in the domestic fowl (Gallus domesticus). Biology of Reproduction 61 400-405. (doi:10.1095/ biolreprod61.2.400)

Fromhage L 2012 Mating unplugged: a model for the evolution of mating plug (dis-)placement. Evolution 66 31-39. (doi:10.1111/j.1558-5646. 2011.01406.x)

Fry CL \& Wilkinson GS 2004 Sperm survival in female stalk-eyed flies depends on seminal fluid and meiotic drive. Evolution 58 1622-1626. (doi:10.1111/j.0014-3820.2004.tb01743.x)

Gage MJG 1994 Associations between body size, mating pattern, testis size and sperm lengths across butterflies. Proceedings of the Royal Society of London. Series B: Biological Sciences 258 247-254. (doi:10.1098/rspb. 1994.0169)

Gage MJG 1995 Continuous variation in reproductive strategy as an adaptive response to population density in the moth Plodia interpunctella. Proceedings of the Royal Society of London. Series B: Biological Sciences 261 25-30. (doi:10.1098/rspb.1995.0112)

Gage MJG \& Freckleton RP 2003 Relative testis size and sperm morphometry across mammals: no evidence for an association between sperm competition and sperm length. Proceedings of the Royal Society of London. Series B: Biological Sciences 270 625-632. (doi:10.1098/rspb. 2002.2258)

Gage MJG \& Morrow EH 2003 Experimental evidence for the evolution of numerous, tiny sperm via sperm competition. Current Biology 13 754-757. (doi:10.1016/S0960-9822(03)00282-3)

Gage MJG, Parker GA, Nylin S \& Wiklund C 2002 Sexual selection and speciation in mammals, butterflies and spiders. Proceedings of the Royal Society of London. Series B: Biological Sciences 269 2309-2316. (doi:10.1098/rspb.2002.2154)

Gage MJG, Macfarlane CP, Yeates S, Ward RG, Searle JB \& Parker GA 2004 Spermatozoal traits and sperm competition in Atlantic salmon: relative sperm velocity is the primary determinant of fertilization success. Current Biology 14 44-47. (doi:10.1016/j.cub.2003.12.028)

Garamszegi LZ, Eens M, Erritzøe J \& Møller AP 2005 Sperm competition and sexually size dimorphic brains in birds. Proceedings of the Royal Society of London. Series B: Biological Sciences 272 159-166. (doi:10.1098/rspb.2004.2940)

García-González F \& Simmons LW 2005a The evolution of polyandry: intrinsic sire effects contribute to embryo viability. Journal of Evolutionary Biology 18 1097-1103. (doi:10.1111/j.1420-9101.2005.00889.x)

García-González F \& Simmons LW 2005b Sperm viability matters in insect sperm competition. Current Biology 15 271-275. (doi:10.1016/j.cub. 2005.01.032)

García-González F \& Simmons LW 2007a Paternal indirect genetic effects on offspring viability and the benefits of polyandry. Current Biology 17 32-36. (doi:10.1016/j.cub.2006.10.054)

García-González F \& Simmons LW 2007b Shorter sperm confer higher competitive fertilization success. Evolution 61 816-824. (doi:10.1111/j. 1558-5646.2007.00084.x)

Gasparini C, Simmons LW, Beveridge M \& Evans JP 2010 Sperm swimming velocity predicts competitive fertilization success in the green swordtail Xiphophorus helleri. PLoS ONE 5 e12146. (doi:10.1371/journal.pone. 0012146)

Ginsberg JR \& Rubenstein DJ 1990 Sperm competition and variation in zebra mating behavior. Behavioral Ecology and Sociobiology 26 427-434. (doi:10.1007/BF00170901)

Goldman N \& Yang Z 1994 A codon-based model of nucleotide substitution for protein-coding DNA sequences. Molecular Biology and Evolution 11 725-736.
Gomendio M \& Roldan ERS 1991 Sperm competition influences sperm size in mammals. Proceedings of the Royal Society of London. Series B: Biological Sciences 243 181-185. (doi:10.1098/rspb.1991.0029)

Gomendio M \& Roldan ERS 2008 Implications of diversity in sperm size and function for sperm competition and fertility. International Journal of Developmental Biology 52 439-447. (doi:10.1387/ijdb.082595mg)

Gomendio M, Martin-Coello J, Crespo C, Magaña C \& Roldan ERS 2006 Sperm competition enhances functional capacity of mammalian spermatozoa. PNAS 103 15113-15117. (doi:10.1073/pnas.0605795103)

Gomendio M, Malo AF, Garde J \& Roldan ERS 2007 Sperm traits and male fertility in natural populations. Reproduction 134 19-29. (doi:10.1530/ REP-07-0143)

Gomendio M, Tourmente M \& Roldan ERS 2011 Why mammalian lineages respond differently to sexual selection: metabolic rate constrains the evolution of sperm size. Proceedings of the Royal Society of London. Series B: Biological Sciences 278 3135-3141. (doi:10.1098/ rspb.2011.0275)

Gravance CG, Liu IKM, Davis RO, Hughes JP \& Casey PJ 1996 Quantification of normal head morphometry of stallion spermatozoa. Journal of Reproduction and Fertility 108 41-46. (doi:10.1530/jrf.0. 1080041)

Haerty W, Jagadeeshan S, Kulathinal RJ, Wong A, Ram KR, Sirot LK, Levesque L, Artieri CG, Wolfner MF, Civetta A et al. 2007 Evolution in the fast lane: rapidly evolving sex-related genes in Drosophila. Genetics 177 1321-1335. (doi:10.1534/genetics.107.078865)

Harcourt AH, Harvey PH, Larson SG \& Short RV 1981 Testis weight, body weight and breeding system in primates. Nature 293 55-57. (doi:10.1038/293055a0)

Harcourt AH, Purvis A \& Liles L 1995 Sperm competition: mating system, not breeding season, affects testes size of primates. Functional Ecology $\mathbf{9}$ 468-476. (doi:10.2307/2390011)

Hayashi F 1998 Sperm co-operation in the fishfly, Parachauliodes japonicus. Functional Ecology 12 347-350. (doi:10.1046/j.1365-2435.1998. 00205.x)

Herndon LA \& Wolfner MF 1995 A Drosophila seminal fluid protein, Acp26Aa, stimulates egg laying in females for 1 day after mating. PNAS 92 10114-10118. (doi:10.1073/pnas.92.22.10114)

Heske EJ \& Ostfeld RS 1990 Sexual dimorphism in size, relative size of testes, and mating systems in North American voles. Journal of Mammology 71 510-519. (doi:10.2307/1381789)

Higginson DM \& Pitnick S 2010 Evolution of intra-ejaculate sperm interactions: do sperm cooperate? Biological Reviews 86 249-270. (doi:10.1111/j.1469-185X.2010.00147.x)

Hirai M, Boersma A, Hoeflich A, Wolf E, Föll J, Aumüller R \& Braun J 2001 Objectively measured sperm motility and sperm head morphometry in boars (Sus scrofa): relation to fertility and seminal plasma growth factors. Journal of Andrology 22 104-110.

Hodgson DJ \& Hosken DJ 2006 Sperm competition promotes the exploitation of rival ejaculates. Journal of Theoretical Biology 243 230-234. (doi:10.1016/j.jtbi.2006.06.024)

Holman L 2009 Drosophila melanogaster seminal fluid can protect the sperm of other males. Functional Ecology 23 180-186. (doi:10.1111/j. 1365-2435.2008.01509.x)

Holman L \& Snook RR 2008 A sterile sperm caste protects brother fertile sperm from female-mediated death in Drosophila pseudoobscura. Current Biology 18 292-296. (doi:10.1016/j.cub.2008.01.048)

Holman L, Freckleton RP \& Snook RR 2008 What use is an infertile sperm? A comparative study of sperm-heteromorphic Drosophila Evolution 62 374-385. (doi:10.1111/j.1558-5646.2007.00280.x)

Holt C, Holt WV, Moore HDM, Reed HCB \& Curnock RM 1997 Objectively measured boar sperm motility parameters correlate with the outcomes of on-farm inseminations: results of two fertility trials. Journal of Andrology 18 312-323.

Hosken DJ 1997 Sperm competition in bats. Proceedings of the Royal Society of London. Series B: Biological Sciences 264 385-392. (doi:10.1098/rspb.1997.0055)

Hosken DJ 1998 Testes mass in megachiropteran bats varies in accordance with sperm competition theory. Behavioral Ecology and Sociobiology $\mathbf{4 4}$ 169-177. (doi:10.1007/s002650050529)

Hosken DJ \& Ward PI 2001 Experimental evidence for testis size evolution via sperm competition. Ecology Letters 4 10-13. (doi:10.1046/j.14610248.2001.00198.x) 
Humphries S, Evans JP \& Simmons LW 2008 Sperm competition: linking form to function. BMC Evolutionary Biology 8 319. (doi:10.1186/14712148-8-319)

Hunter FM \& Birkhead TR 2002 Sperm viability and sperm competition in insects. Current Biology 12 121-123. (doi:10.1016/S0960-9822(01) 00647-9)

Immler S 2008 Sperm competition and sperm cooperation: the potential role of diploid and haploid expression. Reproduction 135 275-283. (doi:10.1530/REP-07-0482)

Immler S \& Birkhead TR 2007 Sperm competition and sperm midpiece size: no consistent pattern in passerine birds. Proceedings of the Royal Society of London. Series B: Biological Sciences 274 561-568. (doi:10.1098/ rspb.2006.3752)

Immler S, Moore HDM, Breed WG \& Birkhead TR 2007a By hook or by crook? Morphometry, competition and cooperation in rodent sperm PLoS ONE 1 e170. (doi:10.1371/journal.pone.0000170)

Immler S, Saint-Jalme M, Lesobre L, Sorci G, Roman Y \& Birkhead TR $2007 b$ The evolution of sperm morphometry in pheasants. Journal of Evolutionary Biology 20 1008-1014. (doi:10.1111/j.1420-9101.2007. 01302.x)

Immler S, Calhim S \& Birkhead TR 2008 Increased postcopulatory sexual selection reduces the intramale variation in sperm design. Evolution 62 1538-1543. (doi:10.1111/j.1558-5646.2008.00393.x)

Immler S, Pryke SR, Birkhead TR \& Griffith SC 2010 Pronounced within-individual plasticity in sperm morphometry across social environments. Evolution 64 1634-1643. (doi:10.1111/j.1558-5646. 2009.00924.x)

Immler S, Pitnick S, Parker GA, Durrant KL, Lüpold S, Calhim S \& Birkhead TR 2011 Resolving variation in the reproductive tradeoff between sperm size and number. PNAS 108 5325-5330. (doi:10.1073/ pnas.1009059108)

Jasko DJ, Little TV, Lein DH \& Foote RH 1992 Comparison of spermatozoal movement and semen characteristics with fertility in stallions: 64 cases (1987-1988). Journal of the American Veterinary Medical Association 200 879-985.

Johnson DDP \& Briskie JV 1999 Sperm competition and sperm length in shorebirds. Condor 101 848-854. (doi:10.2307/1370074)

Joly D \& Schiffer M 2010 Coevolution of male and female reproductive structures in Drosophila. Genetica 138 105-118. (doi:10.1007/s10709009-9392-9)

Joly D, Luck N \& DeJonghe B 2008 Adaptation to long sperm in Drosophila: correlated development of the sperm roller and sperm packaging. Journal of Experimental Zoology 310B 167-178. (doi:10.1002/jez.b. 21167)

Kappeler PM 1997 Intrasexual selection and testis size in strepsirhine primates. Behavioral Ecology 8 10-19. (doi:10.1093/beheco/8.1.10)

Karlsson B 1995 Resource allocation and mating systems in butterflies. Evolution 49 955-961. (doi:10.2307/2410417)

Karlsson B 1996 Male reproductive reserves in relation to mating system in butterflies: a comparative study. Proceedings of the Royal Society of London. Series B: Biological Sciences 263 187-192. (doi:10.1098/rspb. 1996.0030)

Karn RC, Clark NL, Nguyen ED \& Swanson WJ 2008 Adaptive evolution in rodent seminal vesicle secretion proteins. Molecular Biology and Evolution 25 2301-2310. (doi:10.1093/molbev/msn182)

Kelly CD \& Jennions MD 2011 Sexual selection and sperm quantity: metaanalyses of strategic ejaculation. Biological Reviews 86 863-884. (doi:10.1111/j.1469-185X.2011.00175.x)

Kilgallon SJ \& Simmons LW 2005 Image content influences mens semen quality. Biology Letters 1 235-255. (doi:10.1098/rsbl.2005.0324)

Kleven O, Laskemoen T, Fossoy F, Robertson RJ \& Lifjeld JT 2008 Intraspecific variation in sperm length is negatively related to sperm competition in passerine birds. Evolution 62 494-499. (doi:10.1111/j. 1558-5646.2007.00287.x)

Krause W 1995 Computer-assisted semen analysis systems: comparison with routine evaluation and prognostic value in male fertility and assisted reproduction. Human Reproduction 10 60-66.

Kvarnemo C \& Simmons LW 2004 Testes investment and spawning mode in pipefishes and seahorses (Sygnathidae). Biological Journal of the Linnean Society 83 369-376. (doi:10.1111/j.1095-8312.2004. 00395.x)
LaMunyon CW \& Ward S 1998 Larger sperm outcompete smaller sperm in the nematode Caenorhabditis elegans. Proceedings of the Royal Society of London. Series B: Biological Sciences 265 1997-2002. (doi:10.1098/ rspb.1998.0531)

LaMunyon CW \& Ward S 1999 Evolution of sperm size in nematodes: sperm competition favours larger sperm. Proceedings of the Royal Society of London. Series B: Biological Sciences 266 263-267. (doi:10.1098/rspb. 1999.0631)

Lemaître J-F, Ramm SA, Barton RA \& Stockley P 2009 Sperm competition and brain size in mammals. Journal of Evolutionary Biology 22 2215-2221. (doi:10.1111/j.1420-9101.2009.01837.x)

Lemaître J-F, Ramm SA, Hurst JL \& Stockley P 2011 Social cues of sperm competition influence accessory reproductive gland size in a promiscuous mammal. Proceedings of the Royal Society of London. Series B: Biological Sciences 278 1171-1176. (doi:10.1098/rspb.2010.1828)

Levitan DR 2000 Sperm velocity and longevity trade off each other and influence fertilization in the sea urchin Lytechinus variegatus. Proceedings of the Royal Society of London. Series B: Biological Sciences 267 531-534. (doi:10.1098/rspb.2000.1032)

Liljedahl S, Rudolfsen G \& Folstad I 2008 Factors predicting male fertilization success in an external fertilizer. Behavioral Ecology and Sociobiology 62 1805-1811. (doi:10.1007/s00265-008-0609-1)

Lindholmer C 1974 The Importance of seminal plasma for human sperm motility. Biology of Reproduction 10 533-542. (doi:10.1095/biolreprod10.5.533)

Linklater JR, Wertheim B, Wigby S \& Chapman T 2007 Ejaculate depletion patterns evolve in response to experimental manipulation of sex ratio in Drosophila melanogaster. Evolution 61 2027-2034. (doi:10.1111/j. 1558-5646.2007.00157.x)

Liu H \& Kubli E 2003 Sex-peptide is the molecular basis of the sperm effect in Drosophila melanogaster. PNAS 100 9929-9933. (doi:10.1073/pnas. 1631700100)

Lüpold S, Calhim S, Immler S \& Birkhead TR 2009a Sperm morphology and sperm velocity in passerine birds. Proceedings of the Royal Society of London. Series B: Biological Sciences 276 1175-1181. (doi:10.1098/ rspb.2008.1645)

Lüpold S, Linz GM \& Birkhead TR 2009b Sperm design and variation in the new world blackbirds (Icteridae). Behavioral Ecology and Sociobiology 63 899-909. (doi:10.1007/s00265-009-0733-6)

Lüpold S, Linz GM, Rivers JW, Westneat DF \& Birkhead TR 2009c Sperm competition selects beyond relative testes size in birds. Evolution $\mathbf{6 3}$ 391-402. (doi:10.1111/j.1558-5646.2008.00571.x)

Lüpold S, Manier MK, Berben KS, Smith KJ, Daley BD, Buckley SH, Belote JM \& Pitnick S 2012 How multivariate ejaculate traits determine competitive fertilization success in Drosophila melanogaster. Current Biology 22 1667-1672.

Malo AF, Garde JJ, Soler AJ, García AJ, Gomendio M \& Roldan ERS 2005 Male fertility in natural populations of red deer is determined by sperm velocity and the proportion of normal spermatozoa. Biology of Reproduction 72 822-829. (doi:10.1095/biolreprod.104.036368)

Marconato A \& Shapiro DY 1996 Sperm allocation, sperm production and fertilization rates in the bucktooth parrotfish. Animal Behaviour 52 971-980. (doi:10.1006/anbe.1996.0245)

Marshburn PB, McIntire D, Carr BR \& Byrd W 1992 Spermatozoal characteristics from fresh and frozen donor semen and their correlation with fertility outcome after intrauterine insemination. Fertility and Sterility 58 179-186.

Martin PA, Reimers RJ, Lodge JR \& Dziuk PJ 1974 The effect of ratios and numbers of spermatozoa mixed from two males on proportions of offspring. Journal of Reproduction and Fertility 39 251-258. (doi:10.1530/jrf.0.0390251)

Martin-Coello J, Dopazo H, Arbiza L, Ausió J, Roldan ERS \& Gomendio M 2009 Sexual selection drives weak positive selection in protamine genes and high promoter divergence, enhancing sperm competitiveness. Proceedings of the Royal Society of London. Series B: Biological Sciences 276 2427-2436. (doi:10.1098/rspb.2009.0257)

Metz EC, Robles-Sikisaka R \& Vacquier VD 1998 Nonsynonymous substitution in abalone sperm fertilization genes exceeds substitution in introns and mitochondrial DNA. PNAS 95 10676-10681. (doi:10.1073/ pnas.95.18.10676)

Miller GT \& Pitnick S 2002 Sperm-female coevolution in Drosophila. Science 298 1230-1233. (doi:10.1126/science.1076968) 
Møller AP 1988 Ejaculate quality, testes size and sperm competition in primates. Journal of Human Evolution 17 479-488. (doi:10.1016/00472484(88)90037-1)

Møller AP 1989 Ejaculate quality, testes size and sperm production in mammals. Functional Ecology 3 91-96. (doi:10.2307/2389679)

Møller AP 1991 Sperm competition, sperm depletion, paternal care, and relative testis size in birds. American Naturalist 137 882-906. (doi:10.1086/285199)

Møller AP \& Briskie JV 1995 Extra-pair paternity, sperm competition and the evolution of testis size in birds. Behavioral Ecology and Sociobiology 36 357-365. (doi:10.1007/BF00167797)

Montgomerie R \& Fitzpatrick JL 2009 Testis size, sperm size and sperm competition. In Reproductive Biology and Phylogeny of Fishes, pp 1-53. Ed. BGM Jamieson. Enfield, NH: Science Publishers, Inc.

Montoto LG, Magana C, Tourmente M, Martin-Coello J, Crespo C, LuqueLarena JJ, Gomendio M \& Roldan ERS 2011 a Sperm competition, sperm numbers and sperm quality in muroid rodents. PLOS ONE 6 e18173. (doi:10.1371/journal.pone.0018173)

Montoto LG, Sánchez MV, Tourmente M, Martín-Coello J, Luque-Larena JJ, Gomendio M \& Roldan ERS 2011b Sperm competition differentially affects swimming velocity and size of spermatozoa from closely related muroid rodents: head first. Reproduction 142 819-830. (doi:10.1530/ REP-11-0232)

Moore HDM \& Akhondi MA 1996 Fertilizing capacity of rat spermatozoa is correlated with decline in straight-line velocity measured by continuous computer-aided sperm analysis: epididymal rat spermatozoa from the proximal cauda have a greater fertilizing capacity in vitro than those from the distal cauda or vas deferens. Journal of Andrology 17 50-60.

Moore H, Dvorakova K, Jenkins N \& Breed W 2002 Exceptional sperm cooperation in the wood mouse. Nature 418 174-177. (doi:10.1038/ nature00832)

Morrow EH \& Gage MJG 2000 The evolution of sperm length in moths. Proceedings of the Royal Society of London. Series B: Biological Sciences 267 307-313. (doi:10.1098/rspb.2000.1001)

Morrow EH \& Gage MJG 2001 Sperm competition experiments between lines of crickets producing different sperm lengths. Proceedings of the Royal Society of London. Series B: Biological Sciences 268 2281-2286. (doi:10.1098/rspb.2001.1807)

Nakatsuru K \& Kramer DL 1982 Is sperm cheap? Limited male fertility and female choice in the lemon tetra (Pisces, Choracidae) Science 216 753-755. (doi:10.1126/science.216.4547.753)

Nascimento JM, Shi LZ, Meyers S, Gagneux P, Loskutoff NM, Botvinick EL \& Berns MW 2008 The use of optical tweezers to study sperm competition and motility in primates. Journal of the Royal Society, Interface/the Royal Society 5 297-302. (doi:10.1098/rsif.2007.1118)

Olsen PD 1991 Do large males have small testes? A note on allometric variation and sexual size dimorphism in raptors Oikos 60 134-136. (doi:10.2307/3545004)

Olsson M, Madeson T \& Shine R 1997 Is sperm really so cheap? Costs of reproduction in male adders, Vipera berus Proceedings of the Royal Society of London. Series B: Biological Sciences 264 455-459. (doi:10.1098/rspb.1997.0065)

Oppliger A, Naciri-Graven Y, Ribi G \& Hosken DJ 2003 Sperm length influences fertilization success during sperm competition in the snail Viviparus ater. Molecular Ecology 12 485-492. (doi:10.1046/j.1365294X.2003.01748.x)

Parker GA 1970 Sperm competition and its evolutionary consequences in the insects. Biological Reviews 45 525-567. (doi:10.1111/j.1469-185X. 1970.tb01176.x)

Parker GA 1982 Why are there so many tiny sperm? Sperm competition and the maintenance of two sexes Journal of Theoretical Biology 96 281-294. (doi:10.1016/0022-5193(82)90225-9)

Parker GA 1993 Sperm competition games: sperm size and sperm number under adult control. Proceedings of the Royal Society of London. Series B: Biological Sciences 253 245-254. (doi:10.1098/rspb.1993.0110)

Parker GA \& Begon M 1993 Sperm competition games: sperm size and number under gametic control. Proceedings of the Royal Society of London. Series B: Biological Sciences 253 255-262. (doi:10.1098/rspb. 1993.0111)

Parker GA \& Pizzari T 2010 Sperm competition and ejaculate economics. Biological Reviews 85 897-934.
Parker GA, Ball MA, Stockley P \& Gage MJG 1997 Sperm competition games: a prospective analysis of risk assessment. Proceedings of the Royal Society of London. Series B: Biological Sciences 264 1793-1802. (doi:10.1098/rspb.1997.0249)

Parker GA, Immler S, Pitnick S \& Birkhead TR 2010 Sperm competition games: sperm size (mass) and number under raffle and displacement and the evolution of $P_{2}$. Journal of Theoretical Biology 264 1003-1023. (doi:10.1016/j.jtbi.2010.03.003)

Pattarini JM, Starmer WT, Bjork A \& Pitnick S 2006 Mechanisms underlying the sperm quality advantage in Drosophila melanogaster. Evolution 60 2064-2080. (doi:10.1111/j.0014-3820.2006.tb01844.x)

Petersen CW \& Warner RR 1998 Sperm competition in fishes. In Sperm Competition and Sexual Selection, pp 435-464. Eds TR Birkhead\& AP Møller. London: Academic Press.

Pilch B \& Mann M 2006 Large-scale and high-confidence proteomic analysis of human seminal plasma. Genome Biology 7 R40. (doi:10.1186/ gb-2006-7-5-r40)

Pitcher TE, Dunn PO \& Whittingham LA 2005 Sperm competition and the evolution of testis size in birds. Journal of Evolutionary Biology 18 557-567. (doi:10.1111/j.1420-9101.2004.00874.x)

Pitnick S 1996 Investment in testes and the cost of making long sperm in Drosophila. American Naturalist 148 57-80. (doi:10.1086/285911)

Pitnick S, Miller GT, Reagan J \& Holland B 2001 Males' evolutionary responses to experimental removal of sexual selection. Proceedings of the Royal Society of London. Series B: Biological Sciences 268 1071-1080. (doi:10.1098/rspb.2001.1621)

Pitnick S, Hosken DJ \& Birkhead TR 2009a Sperm morphological diversity. In Sperm Biology: an Evolutionary Perspective, pp 69-149. Eds TR Birkhead, DJ Hosken\& S Pitnick. Burlington, MA: Academic Press.

Pitnick S, Wolfner MF \& Suarez SS 2009b Ejaculate-female and spermfemale interactions. In Sperm Biology: an Evolutionary Approach, pp 247-301. Eds TR Birkhead, DJ Hosken\& S Pitnick. London: Academic Press.

Pizzari T \& Foster KR 2008 Sperm sociality: cooperation, altruism, and spite. PLoS Biology 6 e130. (doi:10.1371/journal.pbio.0060130)

Pizzari T \& Parker GA 2009 Sperm competition and sperm phenotype. In Sperm Biology: an Evolutionary Approach, pp 207-245. Eds TR Birkhead, DJ Hosken\& S Pitnick. London: Academic Press.

Pizzari T, Worley K, Burke T \& Froman DP 2008 Sperm competition dynamics: ejaculate fertilising efficiency changes differentially with time. BMC Evolutionary Biology 8 332. (doi:10.1186/1471-2148-8-332)

Poiani A 2006 Complexity of seminal fluid: a review. Behavioral Ecology and Sociobiology 60 289-310. (doi:10.1007/s00265-006-0178-0)

Poulin R \& Morand S 2000 Testes size, body size and male-male competition in acanthocephalan parasites. Journal of Zoology 250 551-558.

Prado CPdA \& Haddad CFB 2003 Testes size in Leptodactylid frogs and occurrence of multimale spawning in the genus Leptodactylus in Brazil. Journal of Herpetology 37 354-362. (doi:10.1670/0022-1511(2003)037 [0354:TSILFA]2.0.CO;2)

Pyron M 2000 Testes mass and reproductive mode of minnows. Behavioral Ecology and Sociobiology 48 132-136. (doi:10.1007/s002650000191)

Radwan J 1996 Intraspecific variation in sperm competition success in the bulb mite: a role for sperm size. Proceedings of the Royal Society of London. Series B: Biological Sciences 263 855-859. (doi:10.1098/rspb. 1996.0126)

Ram RK \& Wolfner MF 2007 Seminal influences: Drosophila Acps and the molecular interplay between males and females during reproduction. Integrative and Comparative Biology 47 427-445. (doi:10.1093/icb/ icm046)

Ramm SA \& Stockley P 2010 Sperm competition and sperm length influence the rate of mammalian spermatogenesis. Biology Letters 6 219-221. (doi:10.1098/rsbl.2009.0635)

Ramm SA, Parker GA \& Stockley P 2005 Sperm competition and the evolution of male reproductive anatomy in rodents. Proceedings of the Royal Society of London. Series B: Biological Sciences 272 949-955. (doi:10.1098/rspb.2004.3048)

Ramm SA, McDonald L, Hurst JL, Beynon RJ \& Stockley P 2009 Comparative proteomics reveals evidence for evolutionary diversification of rodent seminal fluid and its functional significance in sperm competition. Molecular Biology and Evolution 26 189-198. (doi:10.1093/molbev/msn237) 
Rose RW, Nevison CM \& Dixson AF 1997 Testes weight, body weight and mating systems in marsupials and monotremes. Journal of Zoology 243 523-531. (doi:10.1111/j.1469-7998.1997.tb02798.x)

Rowe M \& Pruett-Jones S 2011 Sperm competition selects for sperm quantity and quality in the Australian Maluridae. PLoS ONE 6 e15720. (doi:10.1371/journal.pone.0015720)

Rudolfsen G, Figenschou L, Folstad I, Tveiten H \& Figenschou M 2006 Rapid adjustments of sperm characteristics in relation to social status. Proceedings of the Royal Society of London. Series B: Biological Sciences 273 325-332. (doi:10.1098/rspb.2005.3305)

Scharer L, Ladurner P \& Rieger RM 2004 Bigger testes do work more: experimental evidence that testis size reflects testicular cell proliferation activity in the marine invertebrate, the free-living flatworm Macrostomum sp. Behavioral Ecology and Sociobiology 56 420-425. (doi:10.1007/s00265-004-0802-9)

Sheldon BC 1994 Male phenotype, fertility, and the pursuit of extra-pair copulations by female birds. Proceedings of the Royal Society of London. Series B: Biological Sciences 257 25-30. (doi:10.1098/rspb.1994.0089)

Shulman A, Hauser R, Lipitz S, Frenkel Y, Dor J, Bider D, Mashiach S, Yogev L \& Yavetz H 1998 Sperm motility is a major determinant of pregnancy outcome following intrauterine insemination. Journal of Assisted Reproduction and Genetics 15 381-385. (doi:10.1023/A:1022585000740)

Simmons LW 2001 Sperm Competition and its Evolutionary Consequences in the Insects. Princeton: Princeton University Press.

Simmons LW 2005 The evolution of polyandry: sperm competition, sperm selection, and offspring viability. Annual Review of Ecology and Systematics 36 125-146. (doi:10.1146/annurev.ecolsys.36.102403.112501)

Simmons LW \& García-González F 2008 Evolutionary reduction in testes size and competitive fertilization success in response to the experimental removal of sexual selection in dung beetles. Evolution 62 2580-2591. (doi:10.1111/j.1558-5646.2008.00479.x)

Simmons LW \& Beveridge M 2011 Seminal fluid affects sperm viability in a cricket. PLoS ONE 6 e17975. (doi:10.1371/journal.pone.0017975)

Simmons LW, Wernham J, García-González F \& Kamien D 2003 Variation in paternity in the field cricket Teleogryllus oceanicus: no detectable influence of sperm numbers or sperm length. Behavioral Ecology 14 539-545. (doi:10.1093/beheco/arg038)

Simmons LW, Denholm A, Jackson C, Levy E \& Madon E 2007a Male crickets adjust ejaculate quality with both risk and intensity of sperm competition. Biology Letters 3 520-522. (doi:10.1098/rsbl.2007.0328)

Simmons LW, Emlen DJ \& Tomkins JL 2007b Sperm competition games between sneaks and guards: a comparative analysis using dimorphic male beetles. Evolution 61 2684-2692. (doi:10.1111/j.1558-5646.2007. 00243.x)

Sirot LK, Buehner N, Fiumera AC \& Wolfner MF 2009 Seminal fluid protein depletion and replenishment in the fruit fly, Drosophila melanogaster: an ELISA-based method for tracking individual ejaculates. Behavioral Ecology and Sociobiology 63 1505-1513. (doi:10.1007/s00265-009-0806-6)

Sirot LK, Wolfner MF \& Wigby S 2011 Protein-specific manipulation of ejaculate composition in response to female mating status in Drosophila melanogaster. PNAS 108 9922-9926. (doi:10.1073/pnas.1100905108)

Skjaeraasen JE, Mayer I, Meager JJ, Rudolfsen G, Karlsen O, Haugland T \& Kleven O 2009 Sperm characteristics and competitive ability in farmed and wild cod. Marine Ecology Progress Series 375 219-228. (doi:10.3354/meps07774)

Slatyer RA, Mautz BS, Backwell PRY \& Jennions MD 2012 Estimating genetic benefits of polyandry from experimental studies: a meta-analysis. Biological Reviews 87 1-33. (doi:10.1111/j.1469-185X.2011.00182.x)

Smith CC 2012 Opposing effects of sperm viability and velocity on the outcome of sperm competition. Behavioral Ecology 23 820-826. (doi:10.1093/beheco/ars036)

Smith CC \& Ryan MJ 2011 Tactic-dependent plasticity in ejaculate traits in the swordtail Xiphophorus nigrensis. Biology Letters 7 733-735. (doi:10.1098/rsbl.2011.0286)

Snook RR 2005 Sperm in competition: not playing by the numbers. Trends in Ecology \& Evolution 20 46-53. (doi:10.1016/j.tree.2004.10.011)

Soulsbury CD 2010 Genetic patterns of paternity and testes size in mammals. PLoS ONE 5 e9581. (doi:10.1371/journal.pone.0009581)

Stockley P, Gage MJG, Parker GA \& Møller AP 1997 Sperm competition in fishes: the evolution of testis size and ejaculate characteristics. American Naturalist 149 933-954. (doi:10.1086/286031)
Stutchbury BJ \& Morton ES 1995 The effect of breeding synchrony on extrapair mating systems in songbirds. Behaviour 132 675-690. (doi:10.1163/ 156853995X00081)

Sutkeviciene N, Riskeviciene V, Januskauskas A, Zilinskas H \& Andersson M 2009 Assessment of sperm quality traits in relation to fertility in boar semen. Acta Veterinaria Scandinavica 5153. (doi:10.1186/1751-0147-51-53)

Takami Y \& Sota T 2007 Sperm competition promotes diversity of sperm bundles in Ohomopterus ground beetles. Die Naturwissenschaften 94 543-550. (doi:10.1007/s00114-007-0225-3)

Thomas ML \& Simmons LW 2007 Male crickets adjust the viability of their sperm in response to female mating status. American Naturalist 170 190-195. (doi:10.1086/519404)

Thomas ML \& Simmons LW 2008 Male-derived cuticular hydrocarbons signal sperm competition intensity and affect ejaculate expenditure in crickets. Proceedings of the Royal Society of London. Series B: Biological Sciences 276 383-388. (doi:10.1098/rspb.2008.1206)

Till-Bottraud I, Joly D, Lachaise D \& Snook RR 2005 Pollen and sperm heteromorphism: convergence across kingdoms? Journal of Evolutionary Biology 18 1-18. (doi:10.1111/j.1420-9101.2004.00789.x)

Tourmente M, Gomendio M, Roldan ERS, Giojalas LC \& Chiaraviglio M 2009 Sperm competition and reproductive mode influence sperm dimensions and structure among snakes. Evolution 63 2513-2524. (doi:10.1111/j.1558-5646.2009.00739.x)

Tourmente M, Gomendio M \& Rolando A 2011 a Sperm competition and the evolution of sperm design in mammals. BMC Evolutionary Biology 11 12. (doi:10.1186/1471-2148-11-12)

Tourmente M, Gomendio M \& Roldan ERS $2011 b$ Mass-specific metabolic rate and sperm competition determine sperm size in marsupial mammals. PLOS ONE 6 e21244. (doi:10.1371/journal.pone.0021244)

Vahed K \& Parker DJ 2012 The evolution of large testes: sperm competition or male mating rate? Ethology 118 107-117. (doi:10.1111/j.1439-0310. 2011.01991.x)

Vahed K, Parker DJ \& Gilbert JDJ 2011 Larger testes are associated with a higher level of polyandry, but a smaller ejaculate volume, across bushcricket species (Tettigoniidae). Biology Letters 7 261-264. (doi:10.1098/rsbl.2010.0840)

Veveris-Lowe TL, Kruger SJ, Walsh T, Gardiner RA \& Clements JA 2007 Seminal fluid characterization for male fertility and prostate cancer: kallikrein-related serine proteases and whole proteome approaches. Seminars in Thrombosis and Hemostasis 33 87-99. (doi:10.1055/s-2006958467)

Wagstaff BJ \& Begun DJ 2007 Adaptive evolution of recently duplicated accessory gland protein genes in desert Drosophila. Genetics 177 1023-1030. (doi:10.1534/genetics.107.077503)

Wedell N, Gage MJG \& Parker GA 2002 Sperm competition, male prudence and sperm-limited females. Trends in Ecology \& Evolution 17 313-320. (doi:10.1016/S0169-5347(02)02533-8)

Wigby S \& Chapman T 2004 Female resistance to male harm evolves in response to manipulation of sexual conflict. Evolution 58 1028-1037.

Wigby S, Sirot LK, Linklater JR, Buehner N, Calboli FCF, Bretman A, Wolfner MF \& Chapman T 2009 Seminal fluid protein allocation and male reproductive success. Current Biology 19 751-757. (doi:10.1016/j. cub.2009.03.036)

Willett EL \& Ohms JI 1957 Measurement of testicular size and its relation to production of spermatozoa by bulls. Journal of Dairy Science 40 1559-1569. (doi:10.3168/jds.S0022-0302(57)94678-7)

Youn JS, Cha SH, Park CW, Yang KM, Kim JY, Koong MK, Kang IS, Song IO \& Han SC 2011 Predictive value of sperm motility characteristics assessed by computer-assisted sperm analysis in intrauterine insemination with superovulation in couples with unexplained infertility. Clinical and Experimental Reproductive Medicine 38 47-52. (doi:10.5653/cerm. 2011.38.1.47)

Received 25 July 2012

First decision 23 August 2012

Accepted 14 September 2012 